\title{
Relative sea-level change around the Irish coast
}

\author{
Robin Edwards ${ }^{1}$, Kieran Craven ${ }^{1,2}$ \\ ${ }^{1}$ School of Natural Sciences, Trinity College Dublin, Ireland; 'Department of Geography, Maynooth University,
} Ireland

\section{Introduction}

The Irish coastline is the physical expression of relative sea level (RSL) - the point at which land and ocean surfaces intersect. During the Quaternary, both of these surfaces have experienced significant variations linked to the growth and decay of terrestrial ice sheets. The sea surface rises or falls in response to global-scale changes in ocean volume (classically referred to as eustatic change), although associated perturbations of the Earth's gravity field ensure this response is spatially variable (Farrell and Clark, 1976; Clark et al., 1978; Mörner, $1976,1980)$. Similarly, the land surface falls or rises in response to variations in ice or water loading (isostatic change), in a manner that reflects both the history of loading and the solid Earth's response to it. Hence, RSL change is a complex, spatially-variable, composite signal, produced in response to a wide range of physical processes which integrate mechanisms operating from local to global scales (see Shennan, 2013, 2015).

An accurate picture of RSL change is a prerequisite for understanding the Quaternary history of Ireland. The configuration of the Irish coastline provides fundamental constraints on the limits of the former British Irish Ice Sheet (BIIS); it determines whether ice sheets terminated on land or in the ocean; it defines whether Ireland was connected to Britain and how (pen)insularity may have affected the migration of its flora and fauna. However, the complexity of the RSL signal means that it does not simply inform us about shifting shoreline position. Instead, it contains information on the changing extent and thickness of the BIIS which can help address questions such as when and how fast the ice sheet decayed, and whether RSL rise was a potential cause as well as an effect of this change.

Given the central importance of RSL change, it is unsurprising that sea levels have been a prominent feature of Irish Quaternary science since its foundations in the $19^{\text {th }}$ century. The presence of marine shells at a range of heights above modern sea level has been a longstanding source of interest (e.g. Scouler, 1838; Praeger, 1892, 1896; Hinch, 1908; Kilroe, 1908; Hinch, 1913), and discussion regarding the interpretation of elevated deposits bearing marine-fauna persists to the present day (e.g. Huddart, 1981a,b; Eyles and McCabe, 1989; McCabe, 1995; McCarroll, 2001; McCabe, 2008a; Ballantyne and Ó Cofaigh, this volume, Chapter 5). Similarly, the distribution of 'raised shorelines' around the Irish coast has been an enduring subject of study, with considerable work focussing on their implications for vertical land movement and their use as tools for correlating stratigraphic units (e.g. Coffey and Praeger, 1904; Wright and Muff, 1904; Stephens, 1957; Synge and Stephens, 1966; Synge, 1977a; Warren, 1979, 1985). In the last major compendium of research into the Irish Quaternary record (Edwards and Warren, 1985), a chapter devoted to coastal evolution focussed on shoreline data and its correlation as a way of evaluating RSL change (Synge, 1985).

Over the thirty years since this publication, advances in sea-level science have led to the reevaluation of data and methodologies, and the development of new approaches and perspectives. In fact, this revolution was already underway by the late 1970s, driven in large part by the first of a series of International Geoscience Programme (IGCP) projects with a sea level focus (Project 61: 1974-82), in which the Irish scientific community played an active role (e.g. Carter, 1982). During this and subsequent IGCP Projects (e.g. Project 200, Pirazzoli, 1987) a sea change in perspective was driven by a combination of: theoretical advances (e.g. the concept 'geoidal eustasy', Mörner, 1976); methodological developments in data collection and processing (e.g. 'sea-level index points', see van de Plassche, 1977, 1986); and 
Cite as: Edwards, R., Craven, K., 2017. Relative Sea-Level Change Around the Irish Coast. In: Coxon, P., McCarron, S., Mitchell, F. (eds.) Advances in Irish Quaternary Studies. 181-215. Atlantis Press. DOI: 10.2991/978-94-6239-219-9

computational innovations that enabled the various mechanisms responsible for sea-level change to be modelled (e.g. Walcott, 1972; Clark et al., 1978; Peltier et al., 1978).

The aim of this chapter is to provide an updated synopsis of RSL change around the coast of Ireland, with particular reference to recently published work and areas of current debate. It begins with a brief review of the information obtained from the study of raised shorelines, with particular focus on the evidence for 'pre-glacial' sea levels. It then examines the general patterns of RSL change since the Last Glacial Maximum (LGM) as inferred from geological data and geophysical modelling. The chapter concludes by discussing two aspects of Irish sea-level change with broader interest to the Quaternary community: 1) the timing and significance of RSL maxima in Ireland; 2) the offshore evidence for RSL minima and its implications for Ireland's physical connection to Britain and Europe.

\section{The Quaternary Shorelines of Ireland}

Raised shorelines are perhaps the most visible and striking geological evidence for sea-level change. It is unsurprising, therefore, that they have long attracted attention in the scientific literature and feature in the earliest accounts of RSL change in Ireland (e.g. Hull, 1832). In simple terms, the vertical offset between a 'fossil' shoreline and its modern, actively forming counterpart can be used to infer the general sense and magnitude of RSL change at a particular location. The geological evidence for relict shorelines comes in a wide range of forms, encompassing both erosional and depositional phenomena (Coffey and Praeger, 1904). Erosional features typically take the form of terraces, platforms and scarps cut into rock or glacial sediments (e.g. Stephens, 1963). In places, former cliff-lines replete with abrasion notches, sea-stacks and caves are located inland or buried beneath glacial deposits (e.g. Orme, 1962). Elsewhere, the maximum height at which rock surfaces become cleaned of their glacial mantle (or the minimum height that perched boulders are encountered) is used to define 'washing limits' that constrain the upper bound of marine influence (e.g. Stephens and Synge, 1965). Depositional shoreline features comprise elevated sand and gravel deposits, sometimes containing marine shells, which are collectively grouped under the term 'raised beach' (e.g. Scouler, 1838). Whilst finer grained sediments containing marine fauna are also depositional indicators of higher than present RSL, these are typically indicative of sub-tidal (estuarine to shelf) rather than littoral environments and so are discussed elsewhere (Section 5).

Well over a century of research has documented raised shoreline features exposed discontinuously around the entire coastline of Ireland (e.g. Scouler, 1838; Praeger, 1896; Wright and Muff, 1904). This work has been the subject of several review papers (e.g. Synge, 1977a; Carter, 1983; Devoy, 1983; Synge, 1985; Devoy, 1991, 1995) and so is not recapitulated in detail here. Instead, it is sufficient to note that two principal categories of raised shoreline are evident around the coast of Ireland and that these differ in their character and distribution. The first category comprises shoreline evidence that resides beneath cold stage deposits such as glacial diamict, periglacial 'head' or fluvioglacial outwash. This 'pre-glacial' shoreline classically comprises a raised beach of bedded sands and gravels resting upon a smooth, rock platform that is located above the modern high water mark (Fig. 1). This composite feature, which is best exposed along the southern coast of Ireland, is sometimes referred to as the 'Courtmacsherry' raised beach and rock platform, after the bay in West Cork where Wright and Muff (1904) first described its characteristics in detail (Fig. 2a, Fig. 3). A similar platform (typically minus the beach) is well exposed along the eastern coast of Ireland (Stephens, 1957), and correlations have also been made with platforms on the western (Bryant, 1965) and (tentatively) northern (Stephens, 1957) coasts. The second category consists of a range of shoreline features that post-date the last glacial period in Ireland (the so-called 'late-glacial' and 'post-glacial' shorelines). These shorelines comprise the full spectrum of erosional and depositional forms outlined above, and are best expressed along the northern and north-eastern coasts of Ireland (e.g. Stephens, 1963; Stephens and Synge, 1965) (Fig. 3). 
Cite as: Edwards, R., Craven, K., 2017. Relative Sea-Level Change Around the Irish Coast. In: Coxon, P., McCarron, S., Mitchell, F. (eds.) Advances in Irish Quaternary Studies. 181-215. Atlantis Press. DOI: 10.2991/978-94-6239-219-9

\subsection{The 'Pre-glacial' Shorelines}

The pre-glacial shorelines of Ireland provide tantalising glimpses of former RSL position and have taken on wider significance in the Quaternary literature due to their use as correlative tools. Whilst initially mentioned in the Geological Memoirs of the 1860s, they are most famously associated with exposures along the southern coast of Ireland described in the classic work of Wright and Muff (1904). Figure 1 provides a simplified composite stratigraphic section that shows the principal components of the shoreline and its overlying deposits.

Despite more than a century of work, the ages of the Courtmachserry raised beach and rock platform are uncertain, and the conditions under which they formed are contested. The rock platform has traditionally been viewed as an interglacial feature, although to which warm stage it should be assigned has been the subject of much debate (Mitchell, 1962; Devoy, 1983). Other authors point to the presence of glacial striae and its surface morphology as evidence that the platform is a cold-stage feature sculpted by the passage of ice (e.g. McCabe and Ó Cofaigh, 1996). Detailed mapping over the course of 15 years led Farrington (1966) to conclude that the platform is in fact a composite feature comprising a higher surface dissected by a lower platform or platforms. Whilst the rate of platform formation or destruction is imperfectly understood (Naylor et al., 2010), the possibility such features are metachronous and owe their present form to more than one phase of erosion is widely acknowledged in the Irish literature (e.g. Orme, 1966; Carter, 1982; McKenna, 2002, 2008; Thebaudeau et al., 2013). In light of this uncertainty, it is perhaps unsurprising that the genetic relationship between platform and raised beach is also contested. Some authors view the beach and platform as essentially synchronous warm stage (e.g. Watts and Ross, 1959) or cold stage (e.g. Eyles and McCabe, 1989) phenomena. Conversely, the fact that the raised beach may rest on cold stage deposits (Farrington, 1966) or cover deeply weathered rock surfaces (Bryant, 1965), has led others to conclude that the beach post-dates the cutting of the platform by one or more cycles of RSL change (e.g. Mitchell, 1962; Orme, 1962).

Resolving whether the higher than present RSL responsible for forming these features occurred during a warm or cold interval is an important issue worthy of further study (see Section 5). In addition to elucidating the environments and processes responsible for formation, the development of independently dated chronologies will be critical in realising this goal. Prior to the 1990s, chronological control was limited to indirect inferences based on the contested age of suprajacent (peri)glacial deposits and rare, undiagnostic biostratigraphic data (e.g. Watts and Ross, 1959). In many instances, the age of the overlying cold stage deposits was inferred from chronologies that were developed using the rock platform and beach as a stratigraphic chronohorizon, thereby engendering a degree of circularity in the reasoning (Devoy, 1983). More recently however, a combination of radiocarbon, luminescence and uranium-thorium disequilibrium dating has started to provide the first direct age constraints for the raised beach sediments, although questions still remain regarding their interpretation.

Ó Cofaigh et al. (2012) use optically stimulated luminescence (OSL) to determine the age of deposits at three sites around Courtmacsherry Bay, concluding there is no support for the contention that the raised beach is last interglacial in age (Fig. 2). At Howe's Strand, OSL dates from within cross-stratified sands directly overlying the rock platform returned ages of between $61.2 \pm 9.5$ and $53.1 \pm 7.4$ ka BP. At Courtmacsherry and Broadstrand, OSL dates from within the bedded beach sands and gravels placed their accumulation as sometime after $77.3 \pm 11.8 \mathrm{ka}$ BP. Whilst there is considerable scatter between the single grain and small aliquot dates from the beachface sediments at Courtmacsherry (Fig. 2a), the general chronology is consistent with accumulation during the cold phase of Marine Oxygen Isotope Stage (MIS) 3-4 but prior to the height of the last glacial maximum (Fig. 2b). Importantly, Ó Cofaigh et al. (2012) interpret the cross-stratified sands immediately overlying the beach deposits as being of shallow marine origin, thereby requiring RSL several metres above present during the formation of this unit. They suggest such a situation could arise if modest isostatic depression from early growth of the BIIS occurred before eustatic sea level had fallen 
Cite as: Edwards, R., Craven, K., 2017. Relative Sea-Level Change Around the Irish Coast. In: Coxon, P., McCarron, S., Mitchell, F. (eds.) Advances in Irish Quaternary Studies. 181-215. Atlantis Press. DOI: 10.2991/978-94-6239-219-9

to its LGM minimum (Fig. 2b). This contrasts with the traditional view following Wright and Muff (1904), which interprets the sands as wind-blown deposits formed during a phase of lower RSL.

At Fethard on the Wexford coast, Gallagher and Thorp (1997) report two infra-red stimulated luminescence (IRSL) dates recovered from deposits resting on a rock platform which are interpreted as being an easterly expression of the Courtmacsherry raised beach (Fig. 3). In this instance a date of $161.8 \pm 18.5 \mathrm{ka}$ BP was determined from within the horizontally bedded beach sands and gravels, whilst an age of $128.6 \pm 16.8 \mathrm{ka} \mathrm{BP}$ was returned from the overlying cross-laminated sands. The authors regarded these ages as "...a beginning rather than a conclusion" (Gallagher and Thorp, 1997, pg 87) but opened up the possibility that the raised beach sediments may have been laid down as early as MIS 6 with the overlying sands deposited during the last interglacial (Fig. 2b). In this instance, the authors interpreted the cross-laminated sands as aeolian in origin whilst not ruling out the possibility that they may be shallow-marine deposits (Gallagher and Thorp, 1997). More recently, Gallagher et al. (2015) re-dated the raised beach sediments at Fethard using the OSL approach employed by 0 Cofaigh et al. (2012). This work revised the timing of deposition to MIS 3 - 4, further strengthening the evidence that the shoreline formed during the last cold stage (Fig. 2b).

The only other age data come from the pioneering work of Heijnis et al. (1993) who used uranium-thorium disequilibrium dating (UTD) to establish the age of peat exposed in section around the coast of Tralee Bay, in the west of Ireland (Fig. 3). The sequences, which were first described in detail by Mitchell (1970), comprise a rock platform overlain by a variable deposit of sands and gravels, collectively interpreted as a raised beach and correlated with the pre-glacial shoreline of the south coast (e.g. Mitchell, 1972; Warren, 1985; Heijnis et al., 1993; Gallagher and Thorpe, 1997). Mitchell (1970) reports that peat horizons are interleaved within silts and clays resting upon the raised beach and interprets them as having formed in dune-slacks. Heijnis et al. (1993) date three of these peat layers, showing them to have accumulated sometime between 114ka and $123 \mathrm{ka} \mathrm{BP}$ during MIS 5 (Fig. 2b). Intriguingly, Heijnis et al, (1993) show the organic deposits as occurring beneath the raised beach in the eastern end of the section, with pollen analysis suggesting peat accumulation during a cool, temperate interval.

Collectively, the available dates do not permit a definitive chronology for the 'pre-glacial shoreline' to be developed, although the emerging evidence from the south coast points to at least some of the deposits being MIS $3-4$ in age (Fig. 2b). Possible explanations for the apparent discrepancies between sites include errors in correlation, shoreline diachroneity and erroneous age estimates. Perhaps the only firm conclusion that can be drawn at this stage is that new independently dated field evidence, such as the re-analysis of the sequences at Fethard, will be needed to resolve this issue. In the interim, correlations made on the simple basis of height and litho/morphostratigraphy must be regarded with caution.

\subsection{The Late-glacial and Post-glacial Shorelines}

Whilst Ireland's pre-glacial shorelines are most evident in the southern half of the country, elevated features linked to the final phase of glaciation and the Holocene are best developed along its northern and north-eastern shores where they have been the subject of numerous studies (e.g. Stephens, 1963; Stephens and Synge, 1965; Stephens and McCabe, 1977). Hull (1832) noted that the northward increase in shoreline height along the east coast of Ireland, from about $2 \mathrm{~m}$ above high water around Dublin Bay to $6 \mathrm{~m}$ in NE Antrim, explained why elevated features were most strikingly developed to the north (Fig. 3). Subsequent workers identified the presence of more than one raised shoreline, distinguishing between the lower elevation 'post-glacial' raised beaches of sand, gravel and shell, and the higher elevation 'lateglacial' shorelines, commonly incised into till or outwash gravels and truncated by moraines (see Mitchell and Stephens, 1974; Synge, 1977a, 1977b; Carter, 1982). Over time, various attempts were made to correlate between shoreline fragments to produce overall patterns of shoreline height. Orme (1966) collectively referred to these as 'recoil strandlines', reflecting 
the understanding that the elevation of these features was caused by isostatic rebound following the decay of the BIIS. Complex shoreline correlation diagrams were developed, identifying a suite of late-glacial and post-glacial shorelines, each with different tilts and elevation ranges (e.g. Synge and Stephens, 1966; Synge, 1977a, 1977b; Devoy, 1983). Whilst the details vary, the general pattern of decreasing shoreline height with distance west and south is a common feature of the reconstructions.

The use of shoreline correlation diagrams to elucidate patterns of land level is underpinned by the assumption that the correlated fragments constituting each shoreline are of the same age and the feature formed synchronously along its length. In practice, many shorelines are metachronous (time-transgressive) features and can only be reliably interpreted when accompanied by independent age data (see Devoy, 1983 for a critique). Whilst some of the detailed work in Scotland provides such chronological constraints, particularly on depositional shoreline features (e.g. Smith et al., 2010), this sort of information is typically lacking from Ireland. Accurately dating shoreline features is difficult, especially when dealing with higher energy deposits or features associated with erosion. Where features can be directly dated, it is not always apparent whether the datable material is in situ and therefore reliably reflects the time of formation, or is remobilised and so can simply place an upper limit on its possible age (e.g. Carter, 1993).

The age of late-glacial shorelines is commonly inferred by correlation with associated glacial deposits. In this way, the chronology of RSL change is intimately tied to the glacial history of the region and, as the timing of ice sheet advance and retreat is refined, so the picture of RSL change evolves. Correlations are most robust where they are developed locally and are based on some form of direct dating evidence (e.g. McCabe and Clark, 2003). At larger spatial scales the growing separation between a feature of interest and the material used to date it inevitably renders correlations more susceptible to error. For example, the age of the late-glacial shoreline near Carlingford is ultimately based on a radiocarbon date from a kettle hole on the Isle of Man (Synge, 1977b).

In addition to the difficulties of reliably establishing shoreline age, the use of raised beach deposits as RSL indicators is further complicated by the fact that they may accumulate at a broad range of heights above mean sea level (Devoy, 1983). For example, attempts to distinguish between isostatic and eustatic controls on post-glacial raised shoreline deposits were frustrated by vertical uncertainties in the relationship between the deposits and RSL at the time of their formation (e.g. Mitchell and Stephens, 1974). Carter (1983) provides a comprehensive critique of the use of raised coastal landforms as RSL indicators, emphasising the fact that spatial variations in wind, waves and tides are sufficient to account for the apparent 'tilts' of some of the younger post-glacial shorelines. Similarly, he found no convincing evidence for a high late Holocene 'eustatic' sea level, concluding that most of the shore features along the eastern coast of Ireland dating to the last 5000 years could be explained by extreme events operating at RSL similar to those of today. Reliable compilations are further hampered by a lack of standardisation among early workers in terms of their choice of reference levels for surveying (e.g. high water versus 'sea level'), coupled with the grouping of a range of different geomorphic features into a single composite 'shoreline' (Devoy, 1983).

Consequently, whilst shoreline evidence has been successful in elucidating the general patterns of RSL change, limitations inherent in the shoreline data themselves preclude the development of a more detailed understanding of the mechanisms responsible for it. In order to more reliably reconstruct detailed patterns of change, it is necessary to turn to other forms of data that can more accurately establish the former position of RSL.

\section{Reconstructing Irish RSL Changes since the Last Glacial Maximum}

An established methodology employing sea-level index points (SLIPS) to fix the position of past RSL in time and space (Tooley, 1978; Preuss, 1979; Van de Plassche, 1986) is one legacy of the collaboration between international scientists fostered by various IGCP projects 
and INQUA (sub)commissions (Shennan, 2013). The details of this approach are presented in a string of publications (e.g. Kidson and Heyworth, 1979; Devoy, 1982; Heyworth and Kidson, 1982; Shennan, 1982; 1986; Edwards, 2013; Shennan, 2015). In summary, a sample can be employed as a SLIP if information is available regarding its location (latitude and longitude), its altitude (preferably relative to a national levelling datum), its age (typically established by radiocarbon dating), and its vertical relationship to a contemporaneous tide level (the 'indicative meaning'). The indicative meaning is required to ensure that differences in the vertical distribution of coastal sub-environments and their associated sea-level indicators are accounted for. Failure to do this satisfactorily can result in erroneous 'oscillating' patterns of RSL change.

Traditionally, SLIPs are established at lithostratigraphic contacts between terrestrial and marine sediments with supporting microfossil data (e.g. foraminifera, diatoms) being used to delimit the onset or removal of brackish / marine conditions (Edwards, 2013). It is common practice for SLIPs to be plotted as points on age-altitude diagrams with associated vertical and temporal error terms (e.g. Fig. 5). These points fix the altitude of past RSL at particular moments in time and space, but do not provide any information on the nature of sea-level change between points. Consequently, the resolution at which past RSL changes can be reconstructed is a function of the number and distribution of data points and the relative magnitudes of their associated error terms.

The pattern of RSL change varies markedly in space and this concept is famously encapsulated in the RSL zones of Clark et al. (1978). Ireland has particularly complex, spatially variable and non-monotonic RSL histories due to its location in the transitional region between zone I (glaciated areas) and zone II (collapsing forebulge submergence). Since RSL is an inherently local phenomenon, age-altitude plots should only be compiled from data which have been collected from geographically restricted areas (Tooley, 1978). In Ireland, several studies have produced RSL curves based on SLIPs for particular locations (e.g. Carter, 1982a; Penney, 1983; Sinnott, 1999; Delaney et al, 2012), whilst Carter et al. (1989), Brooks and Edwards (2006) and Brooks et al. (2008) have compared data from multiple sites to examine regional patterns of change. The compilation and comparison of coherent sets of local sealevel data can provide information on differential crustal movements between regions that may be used to model the glacio-isostatic adjustment (GIA) process (see Section 4). Databases containing SLIPs have been assembled for Britain (e.g. Shennan and Horton, 2002) and Ireland (Brooks and Edwards, 2006).

The Irish RSL database predominantly comprises samples recovered from low-energy coastal, estuarine and shallow sub-tidal sedimentary sequences which are classified on the basis of the quality of information associated with each data point (see Brooks and Edwards, 2006 for details). 'Primary' SLIPs possess accurate information on location, altitude and age, and have a quantified vertical relationship to a former tide level, all associated with clearly defined error terms. 'Secondary' SLIPs offer lower quality information and are derived from dated sea-level indicators for which one or more of the core variables is unquantified or associated with significant uncertainty. Whilst primary SLIPs are the most reliable indicators of past RSL their temporal and spatial distribution is comparatively limited in Ireland (Fig. 4a). For example, although several sites along the southern coast, between West Cork and Wexford, have furnished sufficient primary SLIPs to reconstruct the pattern of Holocene RSL change, there are significant data gaps along much of the western, eastern and northern coasts. Similarly, SLIPs are almost entirely restricted to the last 8000 years, with no precise pre-Holocene RSL data currently in the database (Fig. 4c). This is in marked contrast to Britain where the UK database contains an order of magnitude more data points, with SLIPs extending back to 16000 years BP (Shennan and Horton, 2002). Some of these early data come from staircases of uplifted isolation basins in Scotland (e.g. Arisaig, Shennan et al., 2005). Similar basins have yet to be been identified in Ireland. 
Cite as: Edwards, R., Craven, K., 2017. Relative Sea-Level Change Around the Irish Coast. In: Coxon, P., McCarron, S., Mitchell, F. (eds.) Advances in Irish Quaternary Studies. 181-215. Atlantis Press. DOI: 10.2991/978-94-6239-219-9

In many instances, whilst material does not possess an indicative meaning it may still be used to constrain the former altitude of RSL. For example, a freshwater peat deposit or a tree stump are indicative of an environment above the upper limit of marine influence, even if it is not clear precisely how far above this limit the deposit formed. In this way they place an upper limit on the possible position of RSL and are termed 'limiting dates'. Conversely, deposits containing the shells of marine organisms must have accumulated below the upper limit of marine influence and so can also constrain the position of RSL in the past. An important caveat to the use of these kinds of data is that they are in situ: for example, a tree stump embedded within a freshwater peat deposit. Where the material is potentially allocthonous, its use as a RSL indicator becomes more ambiguous since both age and altitude may be affected. In such cases, dates are treated as maximum ages in recognition of the fact that the host deposit may be significantly younger than the material it contains (see Kidson, 1982).

The Irish RSL database distinguishes between 'primary' and 'secondary' limiting dates, both of which can be terrestrial or marine in nature. Primary limiting dates are considered to be in situ and, whilst lacking an indicative meaning, come from contexts in which the age and depositional environment is clear. A sample is classified as a secondary limiting date if one or more of these criteria is not met, such as when the nature of the depositional environment is contested, or if the material is potentially reworked. Limiting data constitute the majority of samples in the Irish RSL database and are virtually the sole source of information concerning late-glacial to early Holocene RSL change (Fig. 4b, Fig. 4c).

When properly screened and combined, these various forms of data can be used to delimit a RSL curve. Figure 5 presents RSL graphs for five areas around the coast of Ireland to illustrate the general patterns of change, data quality and distribution. The patterns revealed by the RSL data are consistent with the broad picture developed from the shoreline data (Fig. 3). The sites from the southern half of Ireland show RSL rise during the Holocene, reaching values within a couple of meters of present by around $5-6 \mathrm{ka}$. This region contains the best quality SLIP data which typically comes from sheltered estuaries and embayments where rising RSL creates accommodation space for low-energy deposits to accumulate. In Kerry and W. Donegal, thinner organic sequences permit the mid to late Holocene pattern of change to be discerned, whilst terrestrial limiting dates constrain the upper bounds of earlier Holocene RSL. Very few precise RSL data exist for western Ireland (Fig. 4a), in part reflecting the predominantly high-energy, rocky coastline which affords limited opportunity for the accumulation and preservation of suitable sedimentary deposits.

The pattern of data from S. Down, situated well within the region of raised shorelines (Fig. 3), is quite different in terms of the kinds of data present and their temporal distribution. Only two secondary SLIPs are available for the late Holocene and these plot at or above modern sea level. The majority of data, in the form of terrestrial and marine limiting dates, come from the early Holocene and indicate RSL was below present. Collectively, these data are consistent with the idea of a slightly higher than present mid-Holocene RSL high-stand (Carter, 1982) and recent work is seeking to refine this picture further (e.g. Roe, 2008; Roe and Swindles, 2008). Two older dates from marine fauna contained within sub-tidal glaciomarine muds place RSL some height above present during the late-glacial (McCabe and Clark, 1998). Hence, the S. Down data are also consistent with the shoreline evidence that suggests high late-glacial RSL was followed by a lower postglacial RSL high-stand (Fig. 3). However, the presence of early Holocene limiting dates below present indicates that rather than a simple pattern of RSL fall driven by isostatic rebound, a more complicated fall - rise - fall pattern may have existed.

Further refinement of the patterns of change is hampered by a fundamental lack of high quality RSL data from many locations around the Irish coast (Fig. 4a). Some of these gaps in coverage reflect difficulties in accessing suitable sedimentary sequences, either because they are deeply buried or submerged, or because conditions did not promote their accumulation and subsequent preservation. The spatial differences in RSL change illustrated in Figure 5 mean that attempting to fill temporal gaps by compiling data from multiple sites is invalid. 
Cite as: Edwards, R., Craven, K., 2017. Relative Sea-Level Change Around the Irish Coast. In: Coxon, P., McCarron, S., Mitchell, F. (eds.) Advances in Irish Quaternary Studies. 181-215. Atlantis Press. DOI: 10.2991/978-94-6239-219-9

Instead, a framework that accounts for regional differences in vertical land movement is needed to assist in the evaluation of patterns of RSL change. In recent years, the development of models capable of simulated the process of GIA has provided such a framework.

\section{Modelling Irish RSL Change since the Last Glacial Maximum}

The British Isles has famously been referred to as one of the most exotic places on Earth from the perspective of glacial rebound modelling (GRM) (Peltier, 1998). This arises from the fact that whilst small $(<1 \mathrm{~m}$ global equivalent sea level at LGM) the BIIS was sufficiently large to produce glacioisostatic rebound of similar magnitude to the 'eustatic' rise over the last $26 \mathrm{ka}$, resulting in highly monotonic RSL histories (Milne et al., 2006). These complex curves are challenging to fit and provide important constraints on shallow Earth model parameters (i.e. lithospheric thickness and upper mantle viscosity).

The use of GRM in sea-level studies is well-established and the current generation of models are built upon a series of developments dating back to the pioneering studies of the 1970s (e.g. Walcott, 1972; Peltier, 1974; Farrell and Clark, 1976; Peltier and Andrews, 1976; Nakada and Lambeck, 1987; Mitrovica and Peltier, 1991; Milne et al. 1999; Milne and Mitrovica, 1996; Milne and Mitrovica 1998; Milne et al., 1999; Peltier et al., 2002, Mitrovica and Milne 2003; Peltier, 2004). A detailed consideration of the modelling process is beyond the scope of this chapter, but useful recent overviews can be found in Milne and Shennan (2013) and Milne (2015). In simple terms, the models comprise three elements: an ice model which describes how grounded ice thickness varies in space and over time; an Earth model which simulates the response of the solid Earth to changes in ice and ocean loading; and an algorithm (the sea level equation) which computes the resulting patterns of RSL, taking into account associated perturbations in the Earth's gravity field and rotation.

Whilst the physical principles underpinning these models are well understood, the precise values of the parameters that define the changing ice load and the rheological properties of the Earth's interior are less well constrained. As a consequence, it is common practice to refine elements of the Earth model to maximise the fit between RSL simulations and RSL data for particular regions. Similarly, where the local ice sheet history is imperfectly known, as is the case for Ireland, altering ice sheet extent and thickness along with the timing of advance and retreat can improve the fit between model and field data. In this way, geophysical modelling can help to constrain plausible limits on past ice sheet growth and decay.

High quality RSL data are an essential component of the iterative modelling process and the detailed database available for Britain spawned a series of studies looking at the British Isles (e.g. Lambeck, 1991, 1993a, 1993b, 1995, 1996; Peltier et al., 2002; Shennan et al., 2000a, 2000b, 2002, 2006; Brooks et al., 2008; Bradley et al., 2009, 2011; Kuchar et al., 2012; Shennan et al., 2012). Since the spatial patterns of RSL change contain information on the processes responsible for generating them, the excellent data coverage from Britain has proven instructive in efforts seeking to separate the influences of earth and ice model parameters (e.g. Lambeck, 1995). The more limited dataset available for Ireland has meant that comparatively few studies have focussed on Irish RSL, and the Irish data cannot provide such strong constraints on earth model parameters (Bradley et al., 2011). Over time, there has been a general convergence among the rheological parameters used in the various model variants. These provide good fits with Holocene RSL data in Britain and Ireland and are consistent with the limited direct evidence of crustal movement provided by GPS measurements (Bradley et al. 2009).

Notable early modelling studies with an Irish focus include the work of Lambeck (1996) and Lambeck and Purcell (2001) which produced a range of RSL curves for parts of the Irish coast. In addition to describing the dominant patterns of RSL during the Holocene, they also evaluated the evidence for higher than present RSL during the late glacial (see Section 5) and generated palaeogeographic reconstructions to explore the existence of a land-bridge between Britain and Ireland (see Section 6). Following publication of the Irish RSL database 
(Brooks and Edwards, 2006) a series of papers incorporating Irish RSL data produced further RSL simulations (Brooks et al., 2008, Bradley et al., 2011; Kuchar et al., 2012). In addition to using an expanded RSL database, which included late-glacial data from Scotland (Shennan et al., 2006b), they also employed more sophisticated ice models that accounted for the effects of topography and bathymetry on ice thickness (Milne et al., 2006). Despite the differences between these models and the earlier work of Lambeck, the general spatial patterns of RSL change are robust and consistent across the studies, reflecting the underlying physical basis of the simulations (Fig. 6). These patterns reflect and refine the picture obtained from shoreline data and SLIPs (Fig. 3, Fig. 5).

The 'success' of the RSL simulations and the tuning of model parameters is defined by the goodness-of-fit between modelled RSL and RSL reconstructed from geological data. However, as Edwards et al (2008) point out, it is important to note that neither modelled nor reconstructed RSLs are direct 'observations' of its former position in space and time. Both modelled and field data have associated uncertainties and require interpretation before RSL can be inferred. In this way, it is erroneous to interpret model - field data misfits as simply being the product of limitations with the model (e.g. McCabe, 2008b). This is particularly the case when dealing with limiting data which may deviate from mean sea level by metres to tens of metres.

SLIPs are also associated with uncertainties that are not fully captured by their error envelopes. For example, the altitude of a reconstruction may be distorted by post-depositional lowering through sediment compaction (e.g. Jelgersma, 1961; Kaye and Barghoorn, 1964; Allen, 2000; Edwards, 2006), or inaccurate vertical corrections due to tidal range change over time (Shennan et al., 2000; Griffiths and Hull, 2015). Similarly, age errors can be introduce where radiocarbon dates are contaminated by older or younger carbon (Sutherland, 1982; Tornqvist et al., 2015). Whilst work is underway to identify and correct for some of these distortions (e.g. Brain, 2015; Brain et al., 2011, 2012, 2015), the source of the data points still needs to be considered when evaluating the possible cause(s) of misfits.

Figure 7 shows a series of comparative plots between RSL data and two iterations of simulated RSL curve for five areas of Ireland since the LGM. An early date of $26 \mathrm{ka}$ is used for the LGM reflecting the far-field low-stand of sea level inferred by Peltier and Fairbanks (2006), coupled with evidence that the BIIS reached its maximum extent several thousand years before the traditional 23-19 ka LGM age of Mix et al. (2001) (see Chiverell and Thomas, 2010; Clark et al, 2012; Ballantyne and Ó Cofaigh, this volume, Chapter 5). It should be noted that maximum local ice volume (loading) need not coincide with maximum ice sheet extent and at present, the precise timing of maximum isostatic depression around the Irish coast is unclear. Each model variant produces a slightly different set of RSL curves and comparison between them gives a general indication of the sensitivity of simulations to altered model parameters. Full details regarding the models are available in Brooks et al. (2008), Bradley et al. (2011) and Kuchar et al. (2012), but the main features are outlined below.

The 'Bradley model' (the best-fit solution of Bradley et al., 2011) is an evolution of the best-fit solution reported in Brooks et al. (2008), incorporating slight modifications to the earth model and eustatic term. The ice sheet is much more laterally extensive than the earlier modelling studies of Lambeck, and considers Ireland to be fully ice covered at the LGM, with ice extending out onto the continental shelf (e.g. Evans et al., 1980; Warren, 1992; McCabe, 1995; Clark and Meehan, 2001; Serjup et al., 2005). The Bradley model uses trim line evidence to constrain the upper limit of ice sheet height, but it corrects for the underlying terrain leading to a thinning of ice over mountainous regions. Whilst the resolution of the ice model is comparatively coarse (time steps $500-1000 \mathrm{yrs}$; spatial grid of $\sim 50 \mathrm{~km}$ ), the time evolution of the ice sheet is distinctly non-monotonic, with several phases of advance and retreat based on the field data available at the time (e.g. McCabe et al. 1998; McCabe and Clark, 2003; McCabe et al., 2005). 
The 'Kuchar model' (the Hub-min scenario of Kuchar et al., 2012) is based on the Bradley model, but deviates significantly from this and all previous modelling studies by using the numerical glaciological model of Hubbard et al. (2009) to generate the BIIS. The principal difference arising from this is that the ice model is considerably thicker than previous versions (Fig. 9b) and this is consistent with the recent reinterpretation of trimlines as englacial thermal transitions, making them indicators of minimum, rather than maximum ice thickness (Ballantyne, 2010; Ballantyne and Stone, 2015). However, the model produces an ice sheet that is much less laterally extensive than has been inferred from field data, suggesting that there is further scope for expanding the ice sheet in future iterations. For the moment, the differences between the output of the Kuchar model and the Bradley model give some indication of the sensitivity of simulations to the local ice sheet loading term.

Commencing in the south where the best quality RSL data exist, modelled and reconstructed RSL show generally good agreement for the Holocene (Fig. 7). In E. Cork, both simulated curves show close fits to the SLIPs during the last 5000 years where data coverage is the highest, although they plot slightly low in the early part of the Holocene when compared to the field data from Ballycotton Bay and Curlane Bank (Carter et al., 1989). In S. Wexford, the early Holocene fit is better, especially for the Bradley model when taking into account the possibility of compaction-driven lowering of some SLIPs from the Beggerin Island sequences (Sinnott, 1999). In general, the differences between the Kuchar and Bradley models are around 2 metres during the Holocene, indicating the comparatively modest impact that the ice loading term has in the region at this time. In contrast, the differences become significant during the late glacial, especially in the south-east where the substantial increase in ice thickness of the Kuchar model around $20 \mathrm{ka}$ drives a RSL high-stand of c. $-13 \mathrm{~m}$ at $19 \mathrm{ka} \mathrm{(>30} \mathrm{m} \mathrm{higher} \mathrm{than}$ for the Bradley model). Both models show RSL at the LGM as substantially below present reflecting the modest influence of ice loading in southern Ireland, coupled with significant drawdown of eustatic sea levels.

The SLIP data from Kerry exhibit a couple of metres of vertical scatter (Fig. 5) whilst the RSL simulations pass through the upper limit of the cloud of index points (Fig. 7). This kind of distribution is consistent with compaction-related post-depositional lowering of some data points. Only terrestrial limiting dates are available for the middle and early Holocene in this region and both RSL curves plot below these for the period prior to c. $6000 \mathrm{BP}$. Both simulated curves show RSL substantially below present at the LGM and during the late glacial, with the Kuchar model producing RSL about $20 \mathrm{~m}$ lower than those of the Bradley model as a result of the more spatially restricted ice sheet.

Further to the north and east, as proximity to the centre of ice loading increases, the influence of inter-model differences in ice sheet thicknesses becomes increasingly notable. In W. Donegal, both models show continuously rising RSL during the Holocene increasing from a low-stand of around $-40 \mathrm{~m} \mathrm{c}$. $15 \mathrm{ka} \mathrm{BP}$. Prior to this low-stand however, the two models show divergent RSL histories, although the rise - fall - rise pattern is a robust feature of both. In the case of the Bradley model whose ice sheet thickness is constrained by the trimline data, the LGM low-stand is similar to that experienced at $15 \mathrm{ka} \mathrm{BP}$, and higher than present RSL is not simulated at any point during deglaciation. In contrast, the Kuchar model with its virtually icefree Ireland at $27 \mathrm{ka} \mathrm{BP}$ and its substantially thicker ice sheet by $21 \mathrm{ka}$ BP, simulates RSL that are lower at LGM and higher during early deglaciation than those of the Bradley model. Of particular note in relation to shoreline data and evidence for higher than present RSL, the Kuchar model simulates RSL above present during the interval 20.5-18.5ka, peaking at around $+14.5 \mathrm{~m}$ c. $19.5 \mathrm{ka}$. In S. Down, the magnitude of the difference is even more extreme, with the Kuchar model simulating peak RSL in excess of $+100 \mathrm{~m}$. Hence, whilst the Bradley model plots RSL below the marine limiting dates provided by glaciomarine muds at Killard Point (McCabe and Clark, 1998), a model with increased ice thickness at this time can easily accommodate them. In the next section, the comparison of GRM simulations with evidence for higher than present late-glacial RSL inferred from glaciomarine muds is considered further. 
Cite as: Edwards, R., Craven, K., 2017. Relative Sea-Level Change Around the Irish Coast. In: Coxon, P., McCarron, S., Mitchell, F. (eds.) Advances in Irish Quaternary Studies. 181-215. Atlantis Press. DOI: 10.2991/978-94-6239-219-9

\section{Sea-Level Maxima and the Deglaciation of Ireland}

The existence of RSL above present during the last glacial has been a topic of considerable debate following the reinterpretation of glacial sequences around the Irish coast by Eyles and McCabe (1989) (Ballantyne and Ó Cofaigh, this volume, Chapter 5; Knight, this volume chapter 6). Under their glaciomarine paradigm, sediments containing marine fauna are considered to be in situ and are interpreted as part of a wider suite of genetically linked deposits reflecting rapid sedimentation at or adjacent to a marine terminating ice margin (McCabe, 2008a) (Fig. 8a). The sedimentological / glaciological arguments for and against this interpretation are beyond the scope of this chapter, but useful summaries can be found in McCarroll (2001), Scourse and Furze (2001) and McCabe (2008a). In the context of sea-level research, the controversy stems from the fact that significant glacioisostatic depression is required to sustain RSL above present during the early phases of deglaciation, at a time when global sea levels were several tens of metres below present. The initial GRM studies of the BIIS were incapable of producing the necessary crustal depression to generate such high RSLs (e.g. Lambeck, 1995), nor could they replicate the rapidity of the inferred variations.

For example, McCabe et al. (2007) present a RSL curve for NE Ireland based on their interpretation of a suite of sedimentological and morphological data (Fig. 8b). They compare this curve with GRM simulations from the region and conclude that, in addition to underestimating the magnitude of glacioisostatic depression, the modelled curves do not reproduce the complexity and rapidity of RSL change inferred from the field data. Critics of the model simulations point to the extremely limited number of pre-Holocene RSL data points that are used in GRM development and highlight inadequacies in the spatio-temporal evolution of the local ice sheet models that they employ (e.g. McCabe, 2008b). In response, the modelling community has highlighted the contested nature of the field data and its interpretation, coupled with the use of inappropriate 'heuristic models' to support the inferred rate and magnitude of GIA (e.g. Lambeck, 1996). Arguably the most plausible explanation for the disagreement is a combination of limitations in both approaches, with the estimation of RSL position from field data and the local ice sheet model being the most likely sources of error.

For example, Edwards et al. (2008) note that the RSL curve for NE Ireland produced by McCabe et al. (2007) is fundamentally flawed since it plots limiting dates as sea-level index points and combines data from locations experiencing differential crustal rebound into a single curve. Both of these aspects are known to produce spurious oscillations in RSL curves (see Section 3). When the data are re-plotted and compared with more recent modelled RSL curves, the apparent discrepancies between the datasets are reduced (Fig. 8b). In most instances, the glaciomarine mud data plot beneath the curves simulated by the Bradley et al. (2011) model, although there is still some indication that magnitude of glacioisostatic depression is underestimated.

An obvious avenue for future research is to modify the local ice sheet component of the GRM, particularly since the trim-line constraint on ice sheet thickness may now be relaxed (see section 4). Figure 9 provides an indication of the potential effects of such modification by comparing the output from the Bradley and Kuchar models with the marine limiting dates developed from radiocarbon dated fauna contained within glaciomarine muds (Fig. 8a). In the north and north-east of Ireland where the ice loading term is the greatest, higher then present RSL is simulated by both models. Whilst the Bradley model (trim-line constrained) fits the data in the earlier phase of deglaciation, the younger dates from sites in Co. Louth and the upper part of the Corvish sequence (Co. Donegal) plot above the curve. In contrast, the Kuchar model has a much thicker ice sheet in this region (Fig. 9b) and this produces significantly higher RSL at LGM and during the early phases of deglaciation.

The simulation of higher than present RSL along the north and north-eastern coastlines of Ireland can be achieved by relatively modest alterations to the BIIS configuration employed in the Bradley model. It is perhaps significant that this is the same stretch of coastline for which there is long-standing field evidence of elevated shorelines and marine deposits (Fig. 3). The 
generation of high RSL to the west and south of this traditional zone of uplift becomes more challenging however. The geometry of GIA response around the Irish coast is closely linked with proximity to the major centres of ice sheet loading over Scotland and Fennoscandinavia (Fig. 6). As a consequence, the production of higher than present RSL to the south and west requires a larger local ice loading term than is needed to produce comparable high-stands in the northeast. This is evident in the simulations for north Co. Mayo which plot between 40 and $60 \mathrm{~m}$ below the limiting dates provided by marine fauna at Belderg Pier and Fiddauntawnanoneen (Fig. 9a). The Kuchar model has an ice sheet that is much less laterally extensive than that of the Bradley model (Fig. 9b) and it remains to be seen whether plausible increases in extent and thickness are capable of generating sufficient glacioisostatic depression to accommodate higher than present RSL during MIS2-4 in these regions. Resolution of this issue will also have important implications for the interpretation of the Courtmacsherry raised beach and the potential existence of a pre-LGM high-stand along the south coast.

\section{Sea-Level Minima and the Insularity of Ireland}

The question of when, where and how Ireland was connected to Britain and Europe has been an enduring subject of interest particularly in relation to its colonisation by plants, animals and humans (e.g. Mitchell, 1972; Devoy, 1985, 1986; Mitchell, 1986; Sleeman et al., 1986; Devoy, 1995; Wingfield, 1995; Lambeck, 1995, 1996; Mitchell and Ryan, 1997; Lambeck and Purcell, 2001; Cooper et al., 2002; Kelley et al., 2006; Edwards and Brooks, 2008; Brooks et al., 2011; Furze et al., 2014; Montgomery et al., 2014). Whilst bathymetry can give some insights, the spatio-temporal variability of RSL low-stands around the Irish coast means that forming a reliable picture of palaeogeography from sparsely distributed data points is challenging. Traditionally, RSL minima have been inferred from the down-cutting of river channels, submerged terraces and, more rarely, terrestrial sediments recovered from offshore boreholes (see Devoy, 1983; Carter et al., 1989; Devoy, 1995). The availability of offshore data is reviewed elsewhere and great strides are being made in the provision of submerged material (McCarron, this volume; Knight, this volume). Nevertheless, these data remain sparse, they are rarely collected with RSL reconstruction as a prime objective, and the recovery of sediment that unambiguously indicates a terrestrial environment is limited.

Integrating the available field evidence to produce regional-scale palaeogeographies can be achieved by combining GRM-simulated RSL histories with topographic and bathymetric data. This approach essentially considers the impact of raising or lowering sea level over a surface of fixed morphology and has been used to produce general assessments of regional palaeogeographic change around Britain and Ireland (Lambeck, 1995, 1996; Shennan et al., 2000; Edwards and Brooks, 2008; Brooks et al., 2011). Figure 10 shows the evolving palaeogeography of Ireland simulated by Edwards and Brooks (2008) based on the GRM of Brooks et al. (2008). These simulations suggest Ireland was isolated from Britain at a comparatively early stage, becoming an island by c. $16 \mathrm{ka}$ BP. Previous modelling work by Lambeck (1995) simulated an extensive landbridge connection that persisted from $20 \mathrm{ka}$ to $13 \mathrm{ka}$, although this was subsequently revised to a more tenuous feature linking Britain and Ireland between $18 \mathrm{ka}$ and $14 \mathrm{ka}$ (Lambeck, 1996). Inter-model differences primarily reflect the ice sheet loading term but are also influenced by factors such as the improved resolution of bathymetric data available for the more recent studies. Despite these differences, all simulations identify the Celtic Sea, south of the Celtic deep, as the most plausible location for a land-bridge. Edwards and Brooks (2008) note that an 'ice-bridge' connection would also have existed between northeast Ireland and Scotland until the demise of the North Channel ice divide shortly after $16 \mathrm{ka}$.

These regional-scale palaeogeographies provide a clearer synoptic picture of change than can be pieced together from fragmentary local records. More importantly, they provide a convenient framework for hypothesis testing and targeted collection of the offshore data that is ultimately required to refute, refine or reaffirm the inferred patterns. For example, Furze et 
al. (2014) examine 12 vibrocores recovered from the Celtic Sea in deeper basins adjacent to the proposed land-bridge position. They report a 'glaciaqueous' mud unit, inferred to be younger than 24-21ka, which this capped by a pervasive gravel lag dating to before c. $14 \mathrm{ka}$ and interpreted as an erosional surface perhaps associated with rising RSL. Whilst there are indications of shallow marine and even intertidal environments in the vicinity, the associated fauna are reworked, highlighting the challenge of finding fragments of these contexts that have escaped erosion during inundation. Ultimately, the authors cannot determine whether mud deposition occurred under glaciomarine or glaciolacustrine conditions on the basis of the lithoand biostratigraphy, but favour a freshwater origin which is consistent with the GRM-based palaeogeographic simulations of Lambeck (see Scourse et al., 2009). Interestingly, the RSL simulations covering the period during which the mud unit was accumulating do not show monotonic RSL rise, indicating that the situation may have been more complex than a single inundation event. For example, the Kuchar model shows a rise - fall - rise scenario for this area which could potentially see surfaces between c. -60 and $-80 \mathrm{~m}$ inundated, re-exposed and then inundated again.

The coarse spatial and temporal resolution of the GRM, coupled with the assumption that the modern topography/bathymetry is a reasonable approximation of past surface morphology, limits the application of the palaeogeographic approach to exploring general patterns of larger scale change. If more detailed, local studies are required, it is necessary to consider the possible modification of sediment surface morphology under the influence of erosion and deposition. One way to achieve this is to integrate seismic data and borehole evidence to evaluate the evolving sedimentary character of the area. For example, Westley et al. (2014) take advantage of the availability of high-resolution multibeam bathymetry and seismic profile data to identify palaeo-landsurfaces that are now buried and submerged offshore of Ramore Head, near Portrush, Co. Antrim. Using a combination of geophysical and borehole data, they backstrip sediment from the palaeolandsurfaces and then use GIA-simulated RSL to produce local palaeogeographic reconstructions which can be used to assess archaeological potential.

Thebaudeau et al. (2013) also exploit the extensive multibeam dataset in this region to explore the evidence for submerged rock-shore platforms off the northern Irish coast between Rathlin Island and Lough Swilly. After detailed mapping of terrace features onshore and offshore, they use a series of GRM-simulated RSL curves to drive a model of shore platform development, comparing the output profiles with the results of the mapping exercise. Whilst numerous subhorizontal platforms are evident in the swath bathymetry, the simulations fail to produce features of comparable size, leading the authors to conclude that many of the rock-cut platforms are likely inherited from one or more earlier phases of RSL. The combination of GRM with models of coastal evolution has significant promise in the future as the quality of spatial data and ways to manipulate it improve.

\section{Summary and Conclusions}

Almost two centuries of research have developed a general picture of RSL change around the coast of Ireland. The Holocene pattern of RSL change is most reliably established and is notable for the considerable spatial variability it exhibits. To the west, south and south-east, RSL rose continuously leaving any direct evidence of the earliest Holocene land surfaces deeply buried or submerged offshore. Few precise data are available before 8000 years ago and the collection of new SLIPs from the late glacial and early Holocene periods should be a focus of future research. In the north and north-east, the complex interplay between eustasy and isostasy resulted in highly non-monotonic RSL change, with periods of higher and lower than present RSL superimposed upon a general GIA-driven falling trend. In this zone of uplift, evidence for late glacial and early Holocene RSL is more prevalent and snapshots of the earliest change at the onset of deglaciation are recorded.

Field evidence for higher than present RSL at a time of low global sea levels requires significant glacioisostatic depression and these data have the potential to provide important 
insights into the growth and decay of the BIIS. GIA models that simulate past RSL have traditionally struggled to replicate the high deglacial levels inferred from geological data. Whilst the current generation of GRM are more consistent with higher than present glacial RSL in the north and east of Ireland, significant misfits remain in the west and south. Further work is needed to investigate whether these misfits are a consequence of errors in inferring RSL from the field evidence, or are due to the underestimation of ice sheet extent and thickness. At the time of writing, the BRITICE-CHRONO (www.britice-chrono.org) and Late Glacial Sea Level Minima (http://sealevelminima.weebly.com) projects are underway and promise to significantly improve our understanding of BIIS evolution and the nature of the RSL evidence located on the continental shelf. The iterative development of future GRM will be reliant on the new information provided by projects such as these. In fact, despite its importance and long history of research, significant gaps remain in our understanding of Irish RSL change and these reflect the comparative paucity of high quality sea-level data. Addressing this fundamental data gap must be a priority for future research.

\section{Acknowledgements}

Thanks to Glenn Milne, Joseph Kuchar and Sarah Bradley for supplying data and comments on the glacial rebound modelling. We are grateful to colleagues for supplying pre-prints of material that was unpublished at the time of writing. We are grateful to Helen Roe for her helpful comments on this chapter. 
Cite as: Edwards, R., Craven, K., 2017. Relative Sea-Level Change Around the Irish Coast. In: Coxon, P., McCarron, S., Mitchell, F. (eds.) Advances in Irish Quaternary Studies. 181-215. Atlantis Press. DOI: 10.2991/978-94-6239-219-9

\section{Figures}

Figure 1: Schematic section of the 'pre-glacial shoreline' which is best developed along the southern coast of Ireland. Occurrence and thickness of individual units varies. (Adapted from Devoy, 1983).

Figure 2a: Stratigraphic log and optically stimulated luminescence (OSL) dates from the raised beach sequence exposed at Courtmacsherry, W. Cork (Adapted from Ó Cofaigh et al., 2012).

Figure 2b: Age ranges of sequences associated with the 'Courtmacsherry' raised beach plotted against a composite far-field record indicative of 'eustatic' sea level change (Adapted from Rohling et al., 2009). Ranges in black are based on optically stimulated luminescence dating (see Ó Cofaigh et al., 2012 and Gallagher et al., 2015). UTD = uranium-thorium disequilibrium dating (see Heijnis et al., 1993). IRSL = Infra-red stimulated luminescence dating (see Gallagher and Thorp, 1997).

Figure 3: Simplified summary distribution of shoreline features with reference to sites mentioned in the text (based on Orme, 1966 and Devoy, 1983). The zero metre isobase marks the limit of elevated 'late-glacial strandlines' as summarised by Orme (1966).

Figure 4: Distribution of sea-level data from the coast of Ireland (updated from Brooks \& Edwards, 2006). Spatial distributions of: a) sea-level index points; b) limiting dates (see text for details). c) Temporal distribution of all data types in 1000 year bins.

Figure 5: Age-altitude data from five areas around the coastline of Ireland illustrating the differences in data type, distribution and pattern of reconstructed change. Sea-level index points are marked as squares whilst limiting dates are shown as triangles (see text for details). Vertical and horizontal bars represent the altitude and age error terms.

Figure 6: Predictions of present-day sea-level change (a) and vertical land uplift (b) produced by the Bradley et al. (2011) model. The contribution to present-day sea-level change from all ice sheets except the former British-Irish Ice sheet (c), and from the British-Irish Ice sheet alone (d) are also shown. (From Bradley et al., 2011).

Figure 7: Age-altitude data from five areas around the coast of Ireland plotted against simulated relative sea-level produced by the 'Bradley' and 'Kuchar' glacial rebound models (see text for details). Data points plotted as in Figure 3.

Figure 8a: Indicators of higher than present glacial relative sea-levels (modified from McCabe, 2008a) along with the inferred low-stand beach of Kelley et al. (2006). All ages are in thousands of calendar years before present. The data from Courtmacsherry are produced by optically stimulated luminescence dating (see Figure 2). All other ages are derived from radiocarbon-dated marine fauna (2-sigma error, calibrated using Calib 7.1, MARINE13 curve. Several inconsistencies in the published radiocarbon data exist, so priority is given to the ${ }^{14} \mathrm{C}$ age as reported in the original publication).

Figure 8b: Relative sea-level change for NE Ireland during the last glacial termination as inferred by McCabe et al. (2007). Data come from the stretch of coast between Rathlin Island and Port (see Fig. 8a). Model simulations for Donaghadee (near Belfast Lough) and Dundalk are as presented in McCabe et al. (2007).

Figure 8c: A revision of the McCabe et al. (2007) plot when radiocarbon-dated samples from the region are processed as sea-level data (see text for details). Data points plotted as in Figure 3. The four solid curves illustrate the differential relative sea-level change experienced along the stretch of coastline from which the data are derived. The original McCabe et al. (2007) reconstructed is plotted as the dashed line.

Figure 9a: Age-altitude data from three areas compared with the simulated relative sea-levels produced by the 'Bradley' and 'Kuchar' glacial rebound models (plotted as in Fig. 7). 
Figure 9b: A comparison of the terrain-corrected British-Irish Ice sheet models used in the 'Bradley' and 'Kuchar' glacial rebound models. The ice sheet models are plotted at their maximum volume which occurs at $21 \mathrm{ka} \mathrm{BP}$ for the Bradley model and $20 \mathrm{ka}$ BP for the Kuchar model (Adapted from Kuchar et al., 2012).

Figure 10: Palaeogeographic reconstructions produced by combining topographic and bathymetric data with the relative sea-level simulations produced by the Brooks et al. (2008) glacial rebound model (adapted from Edwards \& Brooks, 2008). Time steps are: a) 20 ka BP; b) $18 \mathrm{ka} \mathrm{BP}$; ) $16 \mathrm{ka} \mathrm{BP;} \mathrm{d)} 14 \mathrm{ka} \mathrm{BP}$. 
Cite as: Edwards, R., Craven, K., 2017. Relative Sea-Level Change Around the Irish Coast. In: Coxon, P., McCarron, S., Mitchell, F. (eds.) Advances in Irish Quaternary Studies. 181-215. Atlantis Press. DOI: 10.2991/978-94-6239-219-9

\section{References}

Allen JRL (2000) Morphodynamics of Holocene salt marshes: a review sketch from the Atlantic and Southern North Sea coasts of Europe. Quat Sci Rev 19:1155-1231

Ballantyne CK (2010) Extent and deglacial chronology of the last British-Irish Ice Sheet: implications of exposure dating using cosmogenic isotopes. J Quat Sci 25:515-534

Ballantyne CK, Stone JO (2015) Trimlines, blockfields and the vertical extent of the last ice sheet in southern Ireland. Boreas 44:277-287

Ballantyne CK, O'Cofaigh C this volume: insert cross ref

Bradley SL, Milne GA, Teferle FN, Bingley RM, Orliac EJ (2009) Glacial isostatic adjustment of the British Isles: new constraints from GPS measurements of crustal motion. Geophys J Int 178:14-22

Bradley SL, Milne GA, Shennan I, Edwards R (2011) An improved Glacial Isostatic Adjustment model for the British Isles. J Quat Sci 26:541-552

Brain MJ (2015) Compaction. In: Shennan I, Long AJ, Horton BP (eds) Handbook of SeaLevel Research. Wiley, Chichester, pp 452-469

Brain MJ, Long AJ, Petley DN, Horton BP, Allison RJ (2011) Compression behaviour of minerogenic low energy intertidal sediments. Sediment Geol 233:28-41

Brain MJ, Long AJ, Woodroffe SA, Petley DN, Milledge DG, Parnell AC (2012) Modelling the effects of sediment compaction on salt marsh reconstructions of recent sea-level rise. Earth Planet Sci Lett 345-348:180-193

Brain MJ, Kemp AC, Horton BP, Culver SJ, Parnell AC, Cahill N (2015) Quantifying the contribution of sediment compaction to late Holocene salt-marsh sea-level reconstructions, North Carolina, USA. Quatern Res 83:41-51

Brooks AJ, Edwards RJ (2006) The development of a sea-level database for Ireland. Irish Journal of Earth Science 24:13-27

Brooks AJ, Bradley SL, Edwards RJ, Milne GA, Horton B, Shennan I (2008) Postglacial relative sea-level observations from Ireland and their role in glacial rebound modelling. J Quat Sci 23:175-192

Brooks AJ, Bradley SL, Edwards RJ, Goodwyn N (2011) The palaeogeography of Northwest Europe during the last 20,000 years. J Maps 7:573-587

Bryant RH (1965) The 'pre-glacial' raised beach in South-West Ireland. I Geo 5:188-203

Carter RWG (1982) Sea-level changes in Northern Ireland. Proc Geol Assoc 93:7-23

Carter RWG (1983) Raised coastal landforms as products of modern process variations, and their relevance in eustatic sea-level studies: examples from eastern Ireland. Boreas 12:167-182

Carter RWG (1993) Age, origin and significance of the raised gravel barrier at Church Bay, Rathlin Island, County Antrim. Irish Geography 26: 141-146

Carter RWG, Devoy RJN, Shaw J (1989) Late Holocene sea levels in Ireland. J Quat Sci 4:724

Chiverrell RC, Thomas GSP (2010) Extent and timing of the Last Glacial Maximum (LGM) in Britain and Ireland: a review. J Quat Sci 25:535-549

Clark CD, Meehan RT (2001) Subglacial bedform geomorphology of the Irish Ice Sheet reveals major configuration changes during growth and decay. J Quat Sci 16:483-496

Clark CD, Hughes ALC, Greenwood SL, Jordan C, Sejrup HP (2012) Pattern and timing of retreat of the last British-Irish Ice Sheet. Quat Sci Rev 44:112-146

Clark JA, Farrell WE, Peltier WR (1978) Global changes in postglacial sea level: A numerical calculation. Quatern Res 9:265-287

Coffey G, Praeger RL (1904) The Antrim raised beach: a contribution to the neolithic history of the north of Ireland. Proc R Ir Acad Sect C 15:143-200

Cooper JAG, Kelley JT, Belknap DF, Quinn R, McKenna J (2002) Inner shelf seismic stratigraphy off the north coast of Northern Ireland: new data on the depth of the Holocene lowstand. Mar Geol 186:369-387

Delaney CA, Devoy RJN, Jennings SC (2012) Mid- to Late Holocene Relative Sea-Level and Sedimentary Changes on European Atlantic Coasts: Evidence from Castlemaine 
Cite as: Edwards, R., Craven, K., 2017. Relative Sea-Level Change Around the Irish Coast. In: Coxon, P., McCarron, S., Mitchell, F. (eds.) Advances in Irish Quaternary Studies. 181-215. Atlantis Press. DOI: 10.2991/978-94-6239-219-9

Harbour, Southwest Ireland. In: Duffy PJ, Nolan W (eds) At the Anvil: Essays in Honour of William J. Smyth. Geography Publications, Dublin, pp 697-746

Devoy RJN (1982) Analysis of the geological evidence for Holocene sea-level movements in southeast England. Proc Geol Assoc 93:65-90

Devoy RJN (1983) Late Quaternary shorelines in Ireland: an assessment of their implications for isostatic land movement and relative sea-level changes. In: Smith DE, Dawson AG (eds) Shorelines and Isostasy. Academic Press, London, pp 227-254

Devoy RJN (1985) The problem of a late quaternary landbridge between Britain and Ireland. Quat Sci Rev 4:43-58

Devoy RJN Possible land-bridges between Ireland and Britain: a geological appraisal. In: Sleeman DP, Devoy RJN, Woodman PC (eds) Postglacial Colonisation Conference, 1986. Irish Biogeographical Society, Occasional Publication, pp 15-26

Devoy RJN (1991) The study of inferred patterns of Holocene sea-level change from Atlantic and other European coastal margins as a means of testing models of earth crustal behaviour. In: Sabadini R, Lambeck K, Boschi E (eds) Glacial Isostasy, Sea-level and Mantle Rheology, vol 334. Kluwer Academic Publishers, London, pp 213-235

Devoy RJN (1995) Deglaciation, earth crustal behaviour and sea-level changes in the determination of insulatrity: a perspective from Ireland. In: Preece RC (ed) Island Britain: a Quaternary perspective, vol 96. Geol Soc Spec Pub pp 209-242

Edwards KJ, Warren WP (1985) Quaternary Studies in Ireland. In: Edwards KJ, Warren WP (eds) The Quaternary History of Ireland. Academic Press, London,

Edwards R, Brooks A, Shennan I, Milne G, Bradley S (2008) Reply: Postglacial relative sealevel observations from Ireland and their role in glacial rebound modelling. J Quat Sci 23:821-825

Edwards RJ (2006) Mid-to late-Holocene relative sea-level change in southwest Britain and the influence of sediment compaction. Holocene 16:575-587

Edwards RJ (2013) Sedimentary Indicators of Relative Sea-Level Change - Low Energy. In: Elias S, Mock J (eds) Encyclopedia of Quaternary Science (Second Edition), vol 4. Elsevier, Amsterdam, pp 396-408

Edwards RJ, Brooks AJ (2008) The Island of Ireland: Drowning the Myth of an Irish Landbridge? In: Davenport JJ, Sleeman DP, Woodman PC (eds) Mind the Gap: Postglacial Colonisation of Ireland. Special Supplement to The Irish Naturalists' Journal, pp 19-34

Evans DJA, Kenolgy N, Dobson MR, Whittington RJ (1980) The geology of the Malin Sea. Report no. 79/15. Institute of Geological Sciences, London

Eyles N, McCabe AM (1989) The Late Devensian (<22,000BP) Irish Sea Basin: The Sedimentary Record of a Collapsed Ice Sheet Margin. Quat Sci Rev 8:307-351

Farrell WE, Clark JA (1976) On postglacial sea level. Geophys J Int 46:647-667

Farrington A (1966) The early-glacial raised beach in County Cork. Sci Proc R Dublin Soc A 2:197-219

Furze MFA, Scourse JD, Pieńkowski AJ, Marret F, Hobbs WO, Carter RA, Long BT (2014) Deglacial to postglacial palaeoenvironments of the Celtic Sea: lacustrine conditions versus a continuous marine sequence. Boreas 43:149-174

Gallagher C, Thorp M (1997) The age of the Pleistocene raised beach near Fethard, County Wexford, using infra red stimulated luminescence (IRSL). Irish Geography 30:68-89

Gallagher C, Telfer M, Ó Cofaigh C (2015) A marine isotope stage 4 age for Pleistocene raised beach deposits near Fethard, southern Ireland. J Quat Sci 30: 754-763

Griffiths SD, Hill DF (2015). Tidal Modelling. In: : Shennan I, Long AJ, Horton BP (eds) Handbook of Sea-Level Research. Wiley, Chichester, pp 438-451

Heijnis H, Ruddock J, Coxon P (1993) A uranium-thorium dated late Eemian or early midlandian organic deposit from near Kilfenora between Spa and Fenit, Co. Kerry, Ireland. J Quat Sci 8:31-43

Heyworth A, Kidson C (1982) Sea-level changes in southwest England and Wales. Proc Geol Assoc 93:91-111

Hinch JDW (1908) The Occurrence of High-Level Shelly Drift in the Killakee Valley, County Dublin. Irish Nat J 17:99-100 
Hinch JDW (1913) The Shelly Drift of Glenulra and Belderrig, Co. Mayo. Irish Nat J 22:1-6 Hubbard A et al. (2009) Dynamic cycles, ice streams and their impact on the extent, chronology and deglaciation of the British-Irish ice sheet. Quat Sci Rev 28:758-776

Huddart D (1981a) Pleistocene foraminifera from south-east Ireland - some problems of interpretation. Quat Newsl 33:28-41

Huddart D (1981b) Knocknasilloge member of Wexford: Glacio-marine, marine or glaciolacustrine. Quat NewsI 35: 6-11

Hull E (1832) On the Raised Beach of the North-east of Ireland. Paper presented at the Report of the 42nd Meeting of the British Association for the Advancement of Science,

Jelgersma S (1961) Holocene sea level changes in the Netherlands. Mededelingen Geologische Stichting Serie C. VI. 7,

Kaye CA, Barghoorn ES (1964) Late Quaternary Sea-Level Change and Crustal Rise at Boston, Massachusetts, with Notes on the Autocompaction of Peat. Geol Soc Am Bull 75:63-80

Kelley JT, Cooper JAG, Jackson DWT, Belknap DF, Quinn R (2006) Sea-level change and inner shelf stratigraphy off Northern Ireland. Mar Geol 232:1-15

Kidson, C (1982) Sea level changes in the Holocene. Quat Sci Rev 1:121-151

Kidson C, Heyworth A (1979) Sea 'level'. Proc. 1978 Int. Symp. Coastal Evol. In the Quaternary (Sao Paulo) pp 1-27.

Kilroe JR (1908) The Shell-Bearing Drifts of Co. Dublin. Irish Nat J 17:115-118

Knight $\mathrm{J}$ this volume. Insert cross ref

Kuchar J, Milne G, Hubbard A, Patton H, Bradley S, Shennan I, Edwards R (2012) Evaluation of a numerical model of the British-Irish ice sheet using relative sea-level data: implications for the interpretation of trimline observations. J Quat Sci 27:597-605

Lambeck K (1991) Glacial rebound and sea-level change in the British Isles. Terra Nova 3:379-389

Lambeck K (1993a) Glacial rebound of the British Isles-I. Preliminary model results. Geophys J Int 115:941-959

Lambeck K (1993b) Glacial rebound of the British Isles-II. A high-resolution, high-precision model. Geophys J Int 115:960-990

Lambeck K (1995) Late Devensian and Holocene shorelines of the British Isles and North Sea from models of glacio-hydro-isostatic rebound. J Geol Soc 152:437-448

Lambeck K (1996) Glaciation and sea-level change for Ireland and the Irish Sea since Late Devensian/Midlandian time. J Geol Soc 153:853-872

Lambeck K, Purcell AP (2001) Sea-level change in the Irish Sea since the Last Glacial Maximum: constraints from isostatic modelling. J Quat Sci 16:497-506

McCabe AM (1995) Marine Molluscan Shell Dates from two Glaciomarine Jet Efflux Deposits, Eastern Ireland. Ir J Earth Sci 14:37-45

McCabe AM (2008a) Glacial Geology and Geomorphology: The Landscapes of Ireland. Dunedin Academic Press Ltd, Edinburgh

McCabe AM (2008b) Comment: Postglacial relative sea-level observations from Ireland and their role in glacial rebound modelling. A. J. Brooks, S. L. Bradley, R. J. Edwards, G. A. Milne, B. Horton and I. Shennan (2008). Journal of Quaternary Science23: 175192. J Quat Sci 23:817-820

McCabe AM, Clark PU (1998) Ice-sheet variability around the North Atlantic Ocean during the last deglaciation. Nature 392:373-377

McCabe AM, Clark PU (2003) Deglacial chronology from County Donegal, Ireland: implications for deglaciation of the British-Irish ice sheet. J Geol Soc 160:847-855

McCabe AM, Clark PU, Clark J (2005) AMS ${ }^{14} \mathrm{C}$ dating of deglacial events in the Irish Sea Basin and other sectors of the British-Irish ice sheet. Quat Sci Rev 24:1673-1690

McCabe AM, Cooper JAG, Kelley JT (2007) Relative sea-level changes from NE Ireland during the last glacial termination. J Geol Soc 164:1059-1063

McCabe AM, Knight J, McCarron S (1998) Evidence for Heinrich event 1 in the British Isles. J Quat Sci 13:549-568 
McCabe AM, O'Cofaigh C (1996) Upper Pleistocene facies sequences and relative sea-level trends along the south coast of Ireland. Journal of Sedimentary Research 66:376-390

McCarroll D (2001) Deglaciation of the Irish Sea Basin: a critique of the glaciomarine hypothesis. J Quat Sci 16:393-404

McCarron $S$ this volume insert cross ref

McKenna J (2002) Basalt cliffs and shore platforms between Portstewart (Co. Derry) and Portballintrae (Co. Antrim). In: Knight J (ed) Field Guide to the Coastal Environments of Northern Ireland. International Coastal Symposium (ICS). University of Ulster, Coleraine, Northern Ireland, pp 157-164

McKenna J (2008) Quaternary raised shorelines on the north coast of Ireland. In: Whitehouse NJ, Roe H, McCarron S, Knight J (eds) North of Ireland: Field Guide. Quaternary Research Association, London, pp 208-215

Milne GA (2015) Glacial isostatic adjustment. In: Shennan I, Long AJ, Horton BP (eds) Handbook of Sea-Level Research. Wiley, Chichester, pp 421-437

Milne GA, Mitrovica JX (1996) Postglacial sea-level change on a rotating earth: first results from a gravitationally self-consistent sea-level equation. Geophys J Int 126: F13-F20.

Milne GA, Mitrovica JX (1998) Postglacial sea-level change on a rotating Earth. Geophys J Int, 133: 1-19

Milne GA, Shennan I (2013) Isostasy: Glaciation-Induced Sea-Level Change. In: Elias S, Mock $\mathrm{J}$ (eds) Encyclopedia of Quaternary Science (Second Edition) Elsevier:Amsterdam, pp 396-408

Milne GA, Mitrovica JX, Davis JL (1999) Near-field hydro-isostasy: the implementation of a revised sea-level equation. Geophys J Int 139:464-482

Milne GA et al. (2006) Modelling the glacial isostatic adjustment of the UK region. Phil Trans $R$ Soc Lond A 364:931-948

Mitchell GF (1962) Summer Field Meeting in Wales and Ireland (Joint Meeting with the British Association) 7-12 September 1960. Proc Geol Assoc 73:197-213

Mitchell GF (1970) The Quaternary Deposits between Fenit and Spa on the North Shore of Tralee Bay, Co. Kerry. Proc R Ir Acad Sect B 70:141-162

Mitchell GF (1972) The Pleistocene history of the Irish Sea: second approximation. Sci Proc $R$ Dublin Soc A 4:181-199

Mitchell GF (1986) Shell guide to reading the Irish landscape. Country House Press, Dublin

Mitchell GF, Ryan M (1997) Reading the Irish Landscape. TownHouse, Dublin

Mitchell GF, Stephens N (1974) Is there evidence for a Holocene sea-level higher than that of today on the coasts of Ireland? Coll. Int. CNRS 219: 115-125

Mitrovica JX, Milne GA (2003) On post-glacial sea level: I. General theory. Geophys J Int 154:253-267

Mitrovica JX, Peltier WR (1991) On postglacial geoid subsidence over the equatorial oceans. J Geophys Res 96:20053-20071

Mix AC, Bard E, Schneider R (2001) Environmental processes of the ice age: land, oceans, glaciers (EPILOG). Quat Sci Rev 20:627-657

Montgomery WI, Provan J, McCabe AM, Yalden DW (2014) Origin of British and Irish mammals: disparate post-glacial colonisation and species introductions. Quat Sci Rev 98:144-165

Mörner N-A (1976) Eustasy and Geoid Changes. J Geol 84:123-151

Mörner N-A (1980) Eustasy and Geoid Changes as a function of core/mantle changes. In: Mörner N-A (ed) Earth Rheology, Isostasy and Eustasy. Wiley, Chichester, pp 535553

Nakada M, Lambeck K (1987) Glacial rebound and relative sea-level variations: a new appraisal. Geophys J Int 90:171-224

Naylor LA, Stephenson WJ, Trenhaile AS (2010) Rock coast geomorphology: Recent advances and future research directions. Geomorphology 114:3-11

O Cofaigh C, Telfer MW, Bailey RM, Evans DJA (2012) Late Pleistocene chronostratigraphy and ice sheet limits, southern Ireland. Quat Sci Rev 44:160-179

Orme AR (1962) Abandoned and composite Seacliffs in Britain and Ireland. I Geo 4:279-291 
Orme AR (1966) Quaternary Changes of Sea-level in Ireland. Trans Inst Br Geogr 39:127-140

Peltier W, Shennan I, Drummond R, Horton B (2002) On the postglacial isostatic adjustment of the British Isles and the shallow viscoelastic structure of the Earth. Geophys J Int 148:443-475

Peltier WR (1974) The impulse response of a Maxwell Earth. Rev Geophys 12:649-669

Peltier WR (1998) Postglacial variations in the level of the sea: implications for climate dynamics and solid-earth geophysics. Rev Geophys 36: 603-689.

Peltier WR (2004) Global Glacial Isostasy and the Surface of the Ice-Age Earth: The ICE-5G (VM2) Model and Grace. Annu Rev Earth Planet Sci 32:111-149

Peltier WR, Andrews JT (1976) Glacial isostatic adjustment I: The forward problem. Geophys $J$ Int 46:605-646

Peltier WR, Fairbanks RG (2006) Global ice volume and Last Glacial Maximum duration from an extended Barbados sea level record. Quat Sci Rev 25:3322-3337

Peltier WR, Farrell WE, Clark JA (1978) Glacial isostasy and relative sea level: a global finite element model. Tectonophysics 50:81-110

Penney D (1983) Post Glacial sediments and foraminifera at Dundalk, Ireland. Unpublished PhD thesis: Trinity College Dublin

Pirazzoli PA (1987) IGCP Project 200 - Summary Final Report. CNRS-Intergeo, Paris

Praeger RL (1892) Report on the Estuarine Clays of the North-East of Ireland. Proc R Ir Acad 2:212-289

Praeger RL (1896) Report upon the Raised Beaches of the North-East of Ireland, with Special Reference to Their Fauna. Proc R Ir Acad 4:30-54

Preuss $\mathrm{H}$ Progress in computer evaluation of sea-level data within the IGCP Project no. 61 . In: Proceedings of the 1978 International Symposium of Coastal Evolution in the Quaternary, 1979. pp 104-134

Roe HM (2008) Late-glacial and Holocene relative sea-level change in Northern Ireland. In: Whitehouse NJ, Roe HM, McCarron S, Knight J (eds) North of Ireland: Field Guide. Quaternary Research Association, London, pp 21-28

Roe HM, Swindles GT (2008) Holocene sea-level history and coastal evolution of Glenariff. In: Whitehouse NJ, Roe HM, McCarron S, Knight J (eds) North of Ireland: Field Guide. Quaternary Research Association, London, pp 106-116

Scouler J (1838) Account of certain elevated hills of gravel containing marine shells which occur in the County of Dublin. J Geol Soc Dublin 1:266-276

Scourse J, Uehara K, Wainwright A (2009) Celtic Sea linear tidal sand ridges, the Irish Sea Ice Stream and the Fleuve Manche: Palaeotidal modelling of a transitional passive margin depositional system. Mar Geol 259:102-111

Scourse JD, Furze MFA (2001) A critical review of the glaciomarine model for Irish sea deglaciation: evidence from southern Britain, the Celtic shelf and adjacent continental slope. J Quat Sci 16:419-434

Sejrup HP et al. (2005) Pleistocene glacial history of the NW European continental margin. Mar Pet Geol 22:1111-1129

Shennan I (1982) Interpretation of Flandrian sea-level data from the Fenland, England. Proc Geol Assoc 93:53-63

Shennan I (1986) Flandrian sea-level changes in the Fenland I. The geographical setting and evidence of relative sea-level changes. J Quat Sci 1:119-154

Shennan I (2013) Sea Level Studies: Overview. In: Elias SA, Mock J (eds) Encyclopedia of Quaternary Science (Second Edition). Elsevier, Amsterdam, pp 369-376

Shennan I (2015) Handbook of sea-level research: framing research questions. In: Shennan I, Long AJ, Horton BP (eds) Handbook of Sea-Level Research. Wiley, Chichester, pp 349-360

Shennan I, Horton B (2002) Holocene land- and sea-level changes in Great Britain. J Quat Sci 17:511-526

Shennan I, Horton B, Innes J, Gehrels R, Lloyd J, McArthur J, Rutherford M (2000a) Late quaternary sea-level changes, crustal movements and coastal evolution in Northumberland, UK. J Quat Sci 15:215-237 
Shennan I, Lambeck K, Flather R, Horton B, McArthur J, Innes J, Lloyd J, Rutherford M, Wingfield R. (2000b) Modelling western North Sea Palaeogeographies and tidal changes during the Holocene. In: Shennan I, Andrews J (eds) Holocene Land-Ocean Interaction and Environmental Change around the North Sea. Geol Soc Lond Spec Pub 166: 299-319

Shennan I, Peltier WR, Drummond R, Horton B (2002) Global to local scale parameters determining relative sea-level changes and the post-glacial isostatic adjustment of Great Britain. Quat Sci Rev 21:397-408

Shennan I, Hamilton S, Hillier C, Woodroffe S (2005) A 16 000-year record of near-field relative sea-level changes, northwest Scotland, United Kingdom. Quat Int 133-134: 95-106

Shennan I, Bradley S, Milne G, Brooks A, Bassett S, Hamilton S (2006) Relative sea-level changes, glacial isostatic modelling and ice-sheet reconstructions from the British Isles since the Last Glacial Maximum. J Quat Sci 21:585-599

Shennan I, Milne G, Bradley S (2012) Late Holocene vertical land motion and relative sealevel changes: lessons from the British Isles. J Quat Sci 27: 64-70

Sinnott A (1999) Holocene Sea-Level Changes From the South and Southeast Coasts of Ireland. University College Cork

Sleeman DP, Devoy RJ, Woodman PC (1986) Proceedings of the Postglacial Colonization Conference, University College Cork, 15-16 October 1983. Occ Publ Ir Biogeog Soc 1.

Smith DE et al. (2010) Holocene relative sea levels and related prehistoric activity in the Forth lowland, Scotland, United Kingdom. Quat Sci Rev 29:2382-2410

Stephens N (1957) Some Observations on the "Interglacial" Platform and the Early PostGlacial Raised Beach on the East Coast of Ireland. Proc R Ir Acad Sect B 58:129-149

Stephens N (1963) Late-Glacial Sea-Levels in North-East Ireland. I Geo 4:345-359

Stephens N, McCabe AM (1977) Late-Pleistocene ice movements and patterns of Late and Post glacial shorelines on the east coast of Ulster. In: Kidson C, Tooley MJ (eds) Quaternary history of the Irish Sea. Sea House Press, Liverpool, pp 179-198

Stephens N, Synge FM (1965) Late-Pleistocene Shorelines and Drift Limits in North Donegal. Proc R Ir Acad Sect B 64:131-153

Sutherland DG (1982) Dating and Associated Methodological Problems in the Study of Quaternary Sea-Level Changes. In: Harding AF (ed) Climate Change in Later Prehistory. University Press, Edinburgh, pp 165-197

Synge FM (1977a) The coasts of Leinster. In: Kidson C, Tooley MJ (eds) The Quaternary history of the Irish Sea. Seel House Press, Liverpool, pp 179-198

Synge FM (1977b) Records of sea levels during the Late Devensian. Phil Trans R Soc Lond B 280:211-228

Synge FM (1985) Coastal Evolution. In: Edwards KJ, Warren WP (eds) The Quaternary History of Ireland. Academic Press, London, pp 115-131

Synge FM, Stephens N (1966) Late and post glacial shorelines and ice limits in Argyll and north-east Ulster. Trans Inst Br Geogr 39:101-125

Thébaudeau B, Trenhaile AS, Edwards RJ (2013) Modelling the development of rocky shoreline profiles along the northern coast of Ireland. Geomorphology 203:66-78

Tooley MJ (1978) Sea-level changes. North-West England during the Flandrian Stage. Clarendon Press, Oxford

Törnqvist TE, Rosenheim BE, Hu P, Fernandez AB (2015) Radiocarbon dating and calibration. In: Shennan I, Long AJ, Horton B (eds) Handbook of Sea-Level Research. Wiley, Chichester, pp 3-28

Van de Plassche O (1977) A manual for sample collection and evaluation of sea level data. Institute for Earth Sciences, Amsterdam

van de Plassche O (1986) Sea-Level Research: A Manual for the Collection and Evaluation of Data. Geo Books, Norwich, UK

Walcott RI (1972) Late Quaternary vertical movements in Eastern North America. Rev Geophys 10:849-884 
Warren WP (1979) The stratigraphic position and age of the Gortian Interglacial deposits. GSI Bulletin 2:315-332

Warren WP (1985) Stratigraphy. In: Edwards KJ, Warren WP (eds) The Quaternary History of Ireland. Academic Press, London, pp 39-65

Warren WP (1992) Drumlin orientation and the pattern of glaciation in Ireland. Sveriges Geologiska Undersokning, Research Papers, Ceries Ca 81:359-366

Watts WA, Ross R (1959) Interglacial Deposits at Kilbeg and Newtown, Co. Waterford. Proc $R$ Ir Acad Sect B 60:79-134

Westley K, Plets R, Quinn R (2014) Holocene Paleo-Geographic Reconstructions of the Ramore Head Area, Northern Ireland, Using Geophysical and Geotechnical Data: Paleo-Landscape Mapping and Archaeological Implications. Geoarchaeology 29:411430

Wingfield RTR (1995) A model of sea-levels in the Irish and Celtic seas during the endPleistocene to Holocene transition. In: Preece RC (ed) Island Britain. Geol Soc Lond Spec Pub 96: 209-242

Wright WB, Muff HB (1904) The pre-glacial raised beach of the south coast of Ireland. Sci Proc R Dublin Soc A 10:250-324 


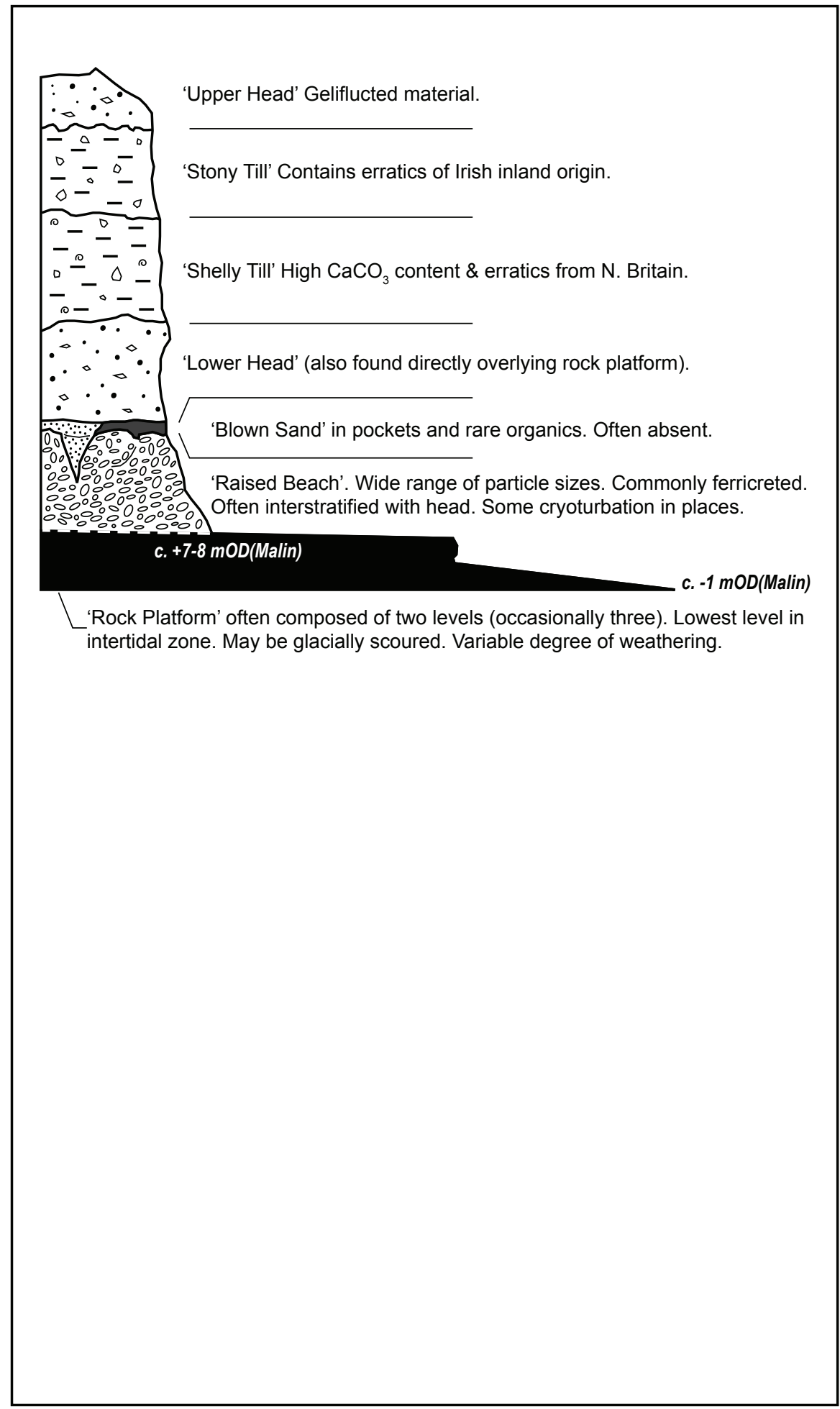




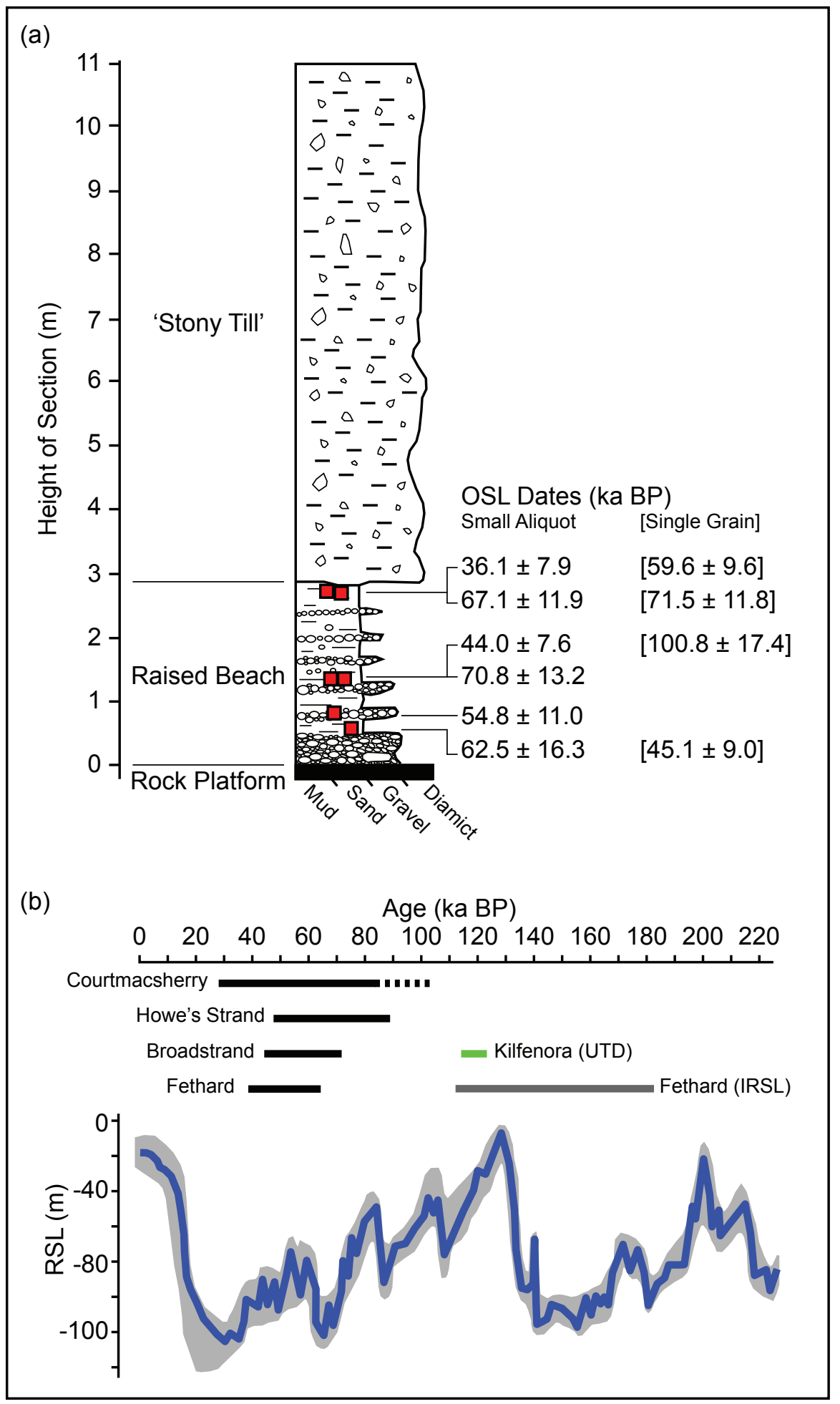




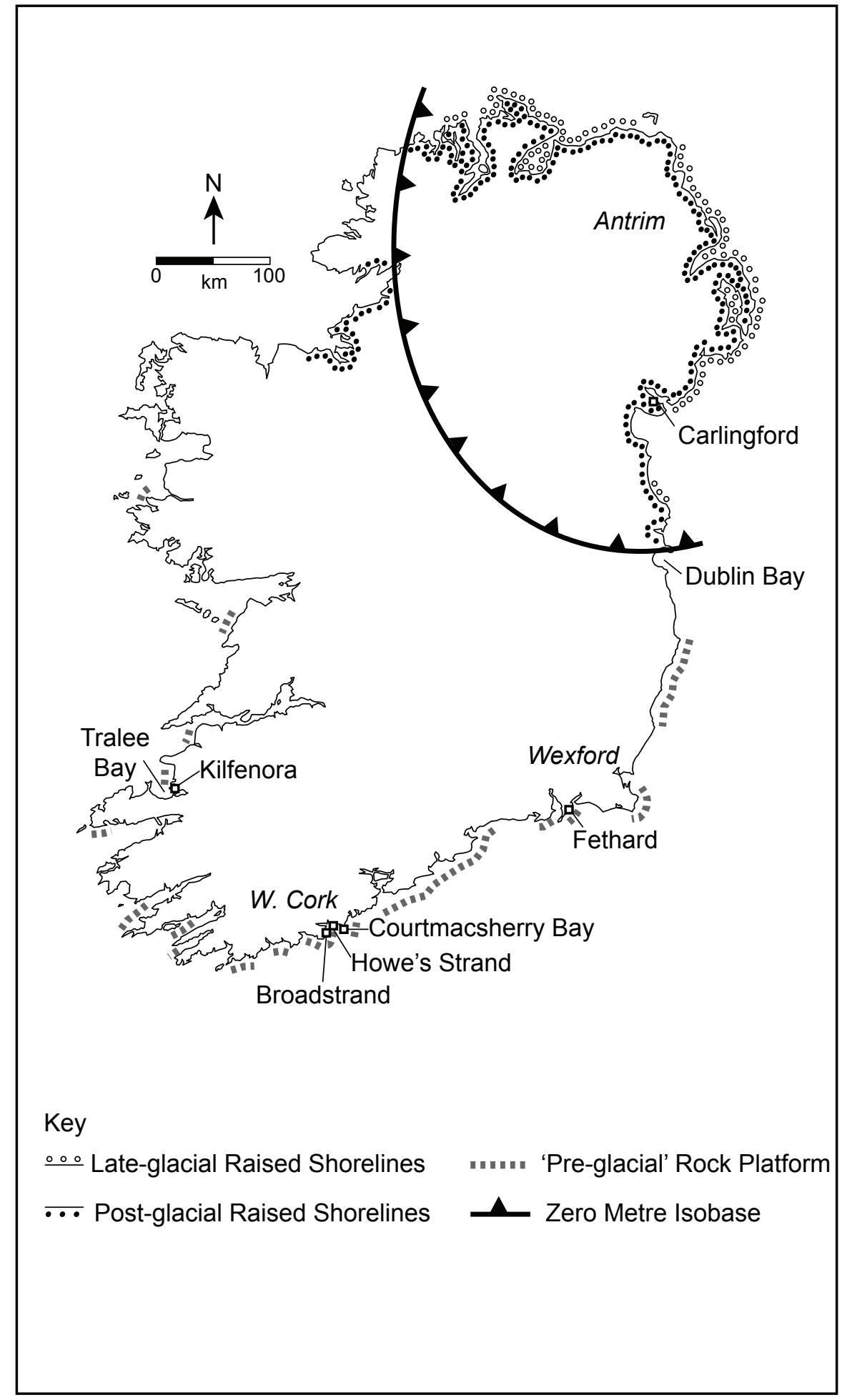




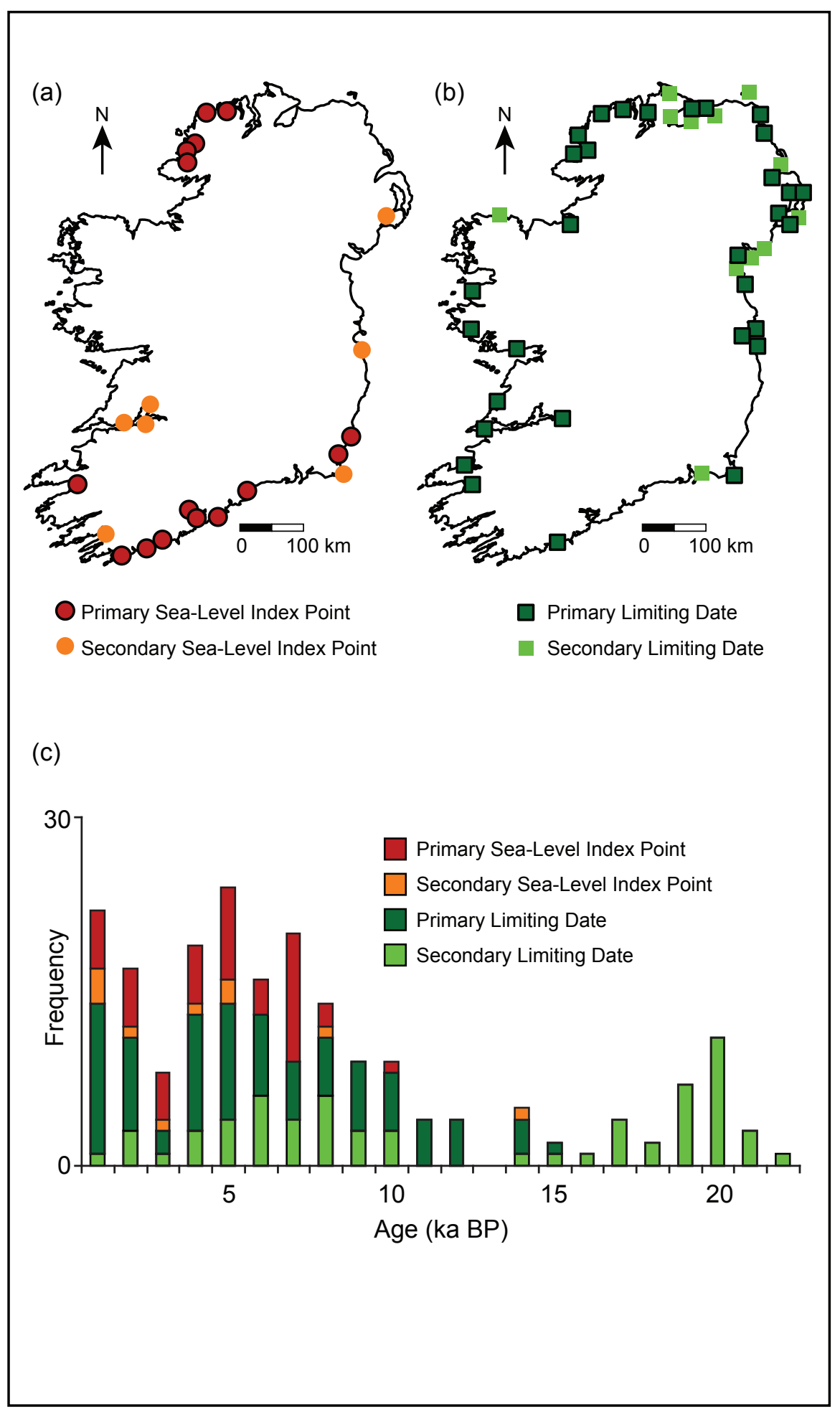



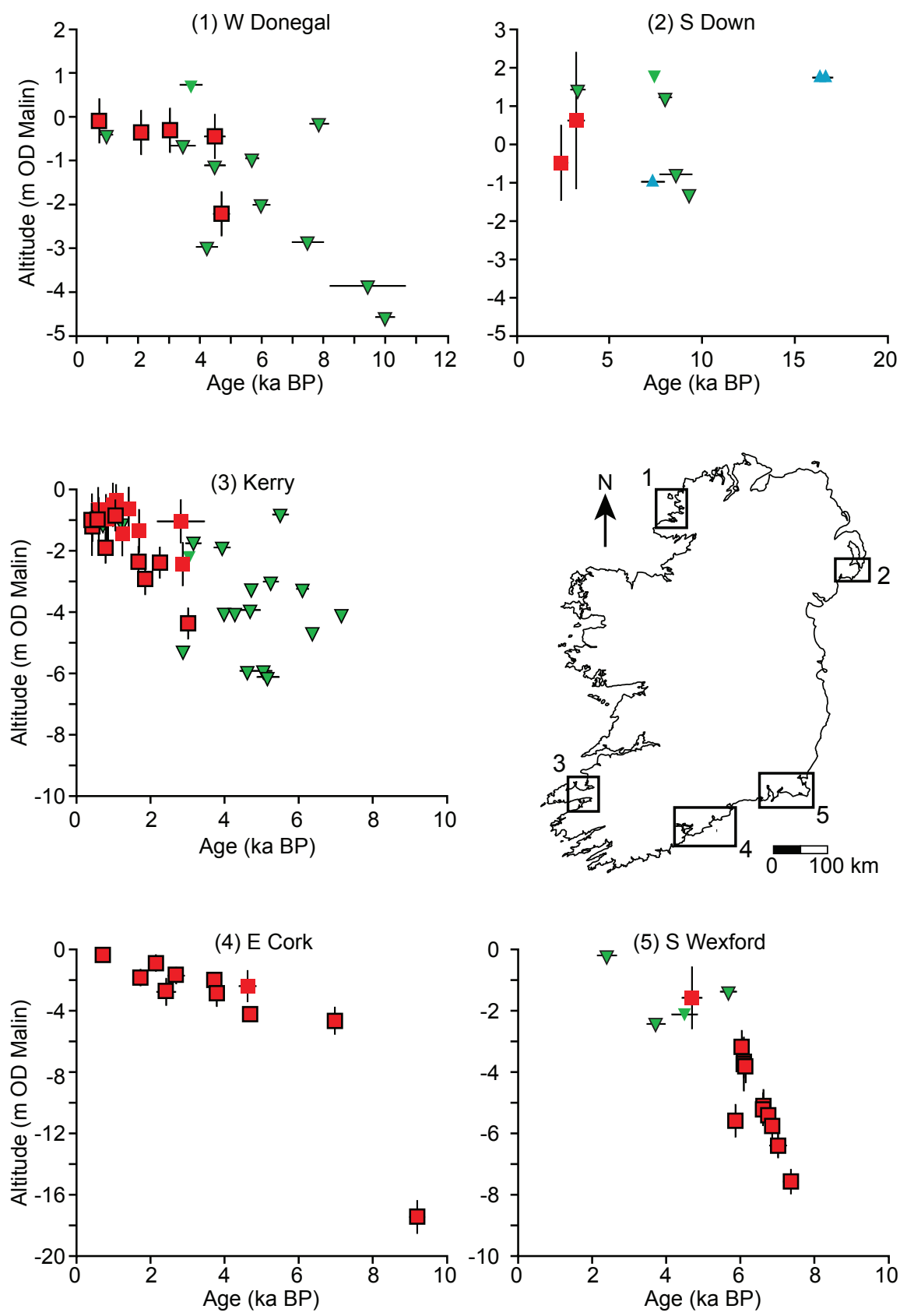

Sea Level Index Point Limiting Dates 

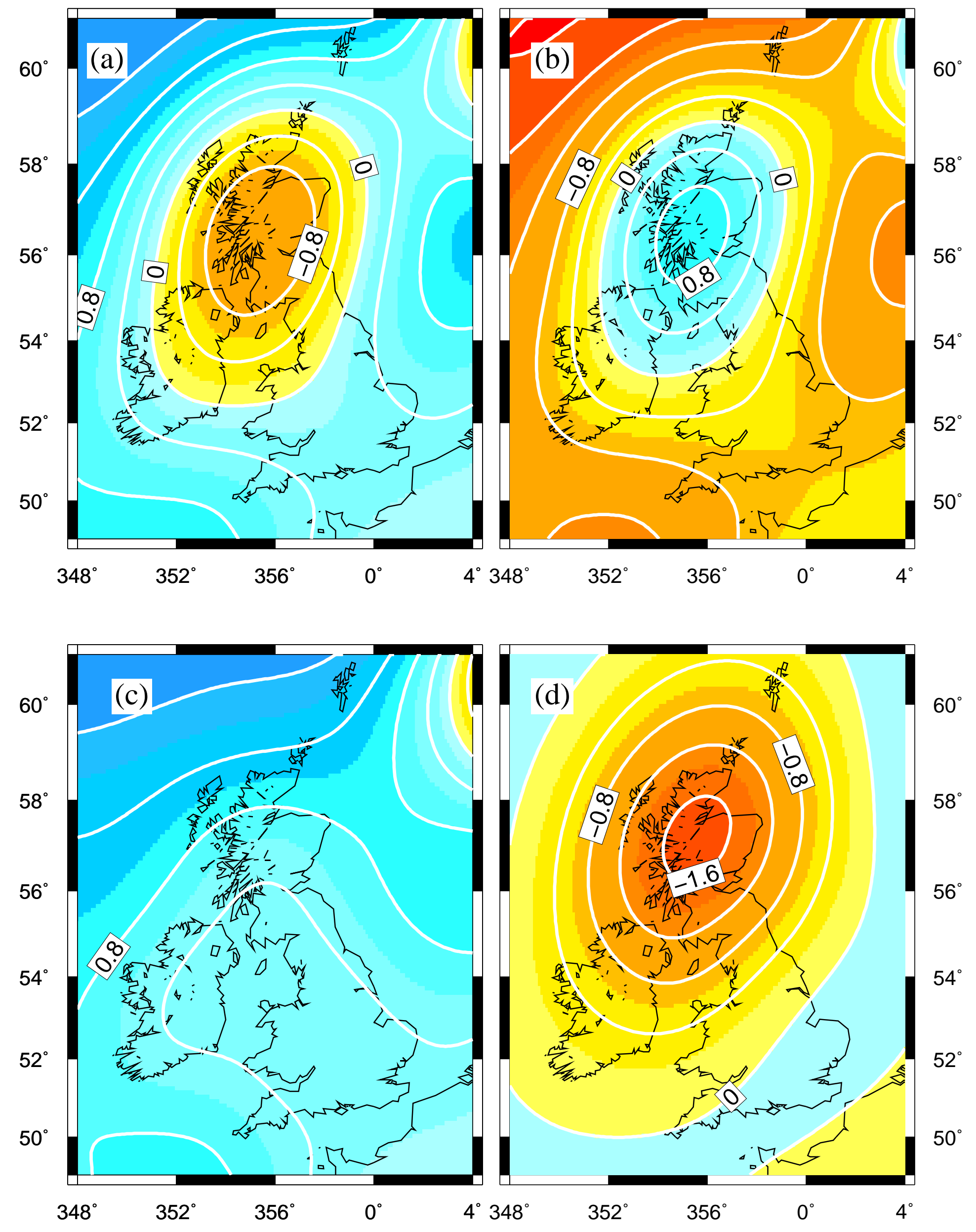

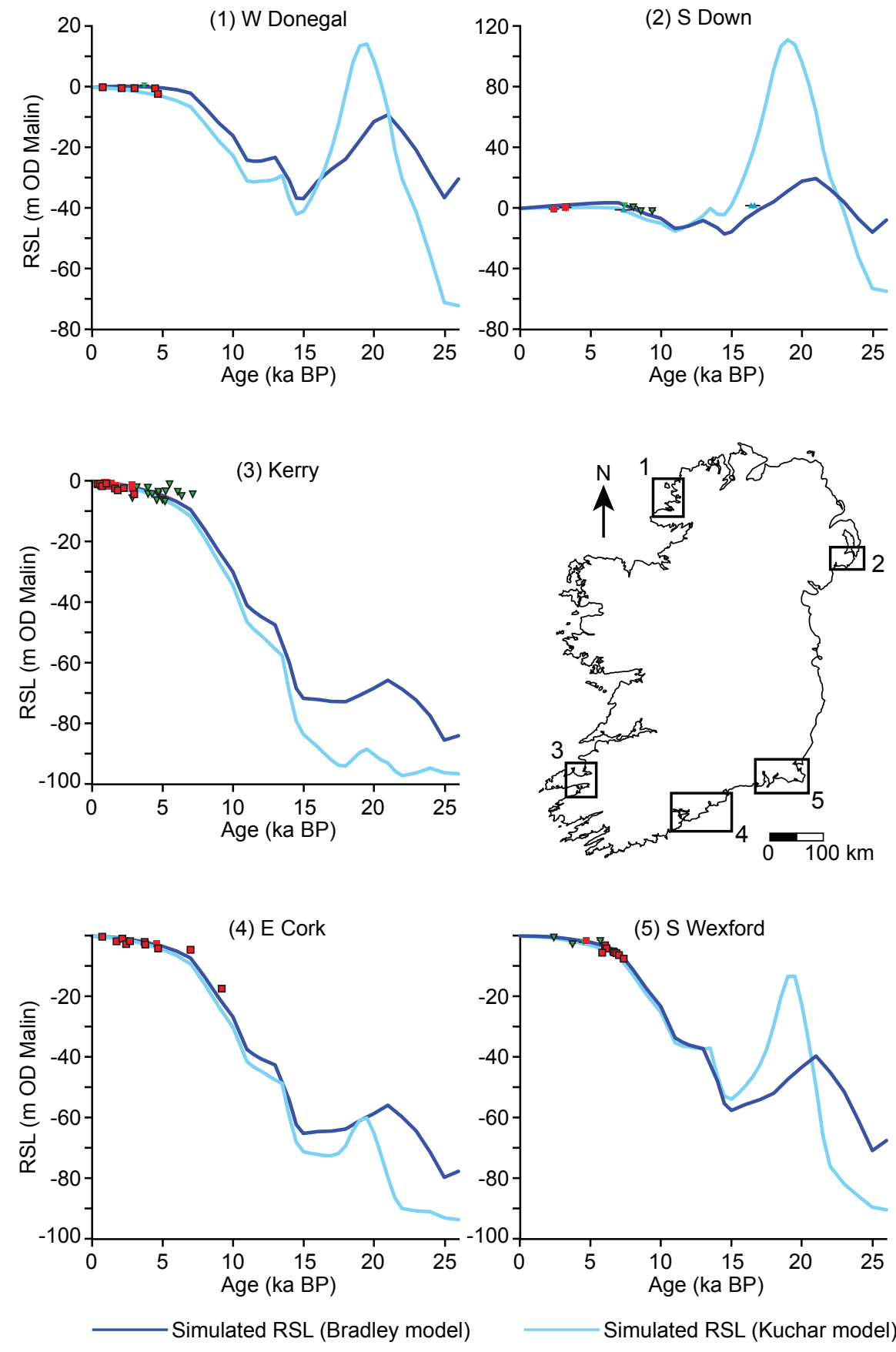

Simulated RSL (Kuchar model) 


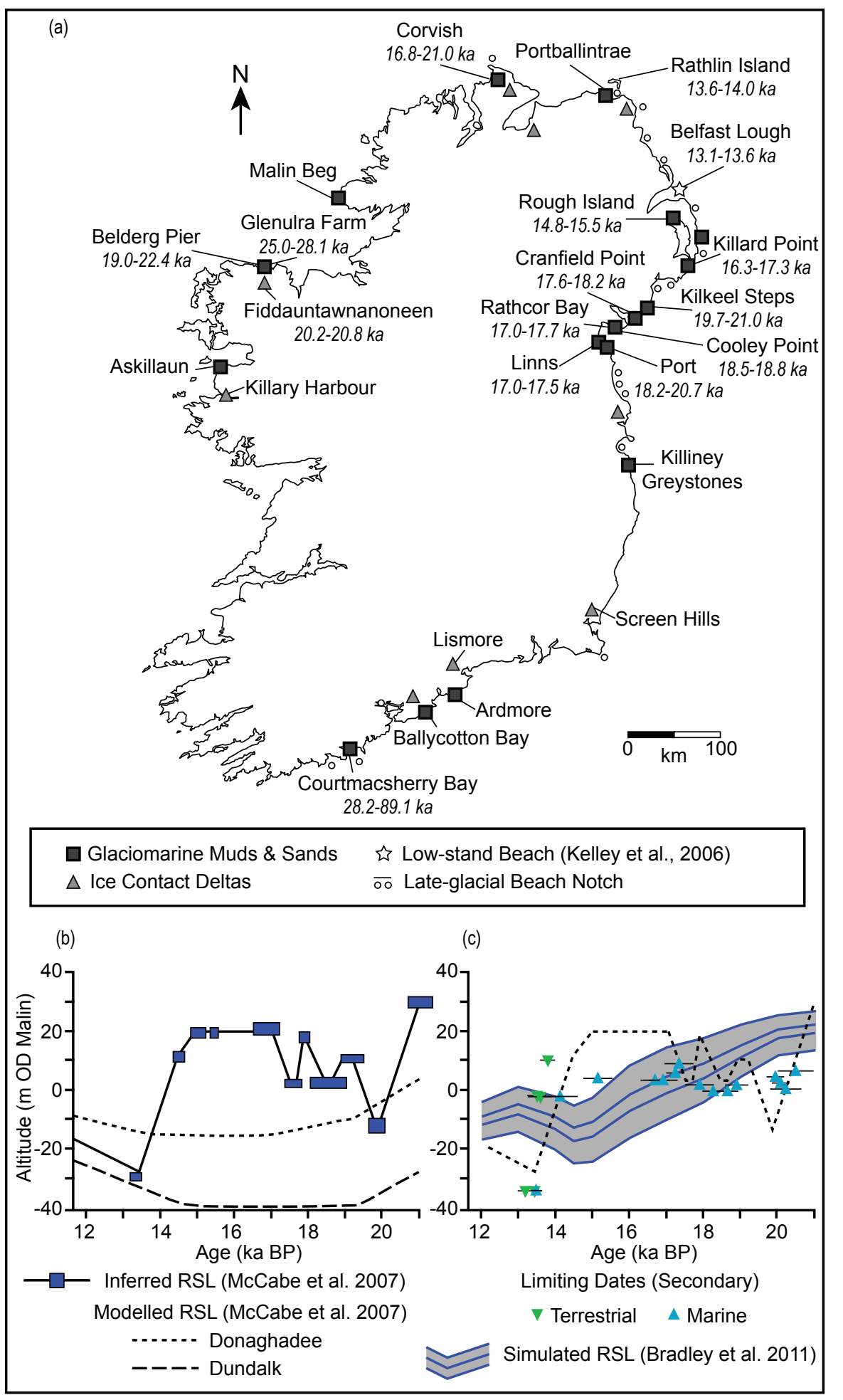




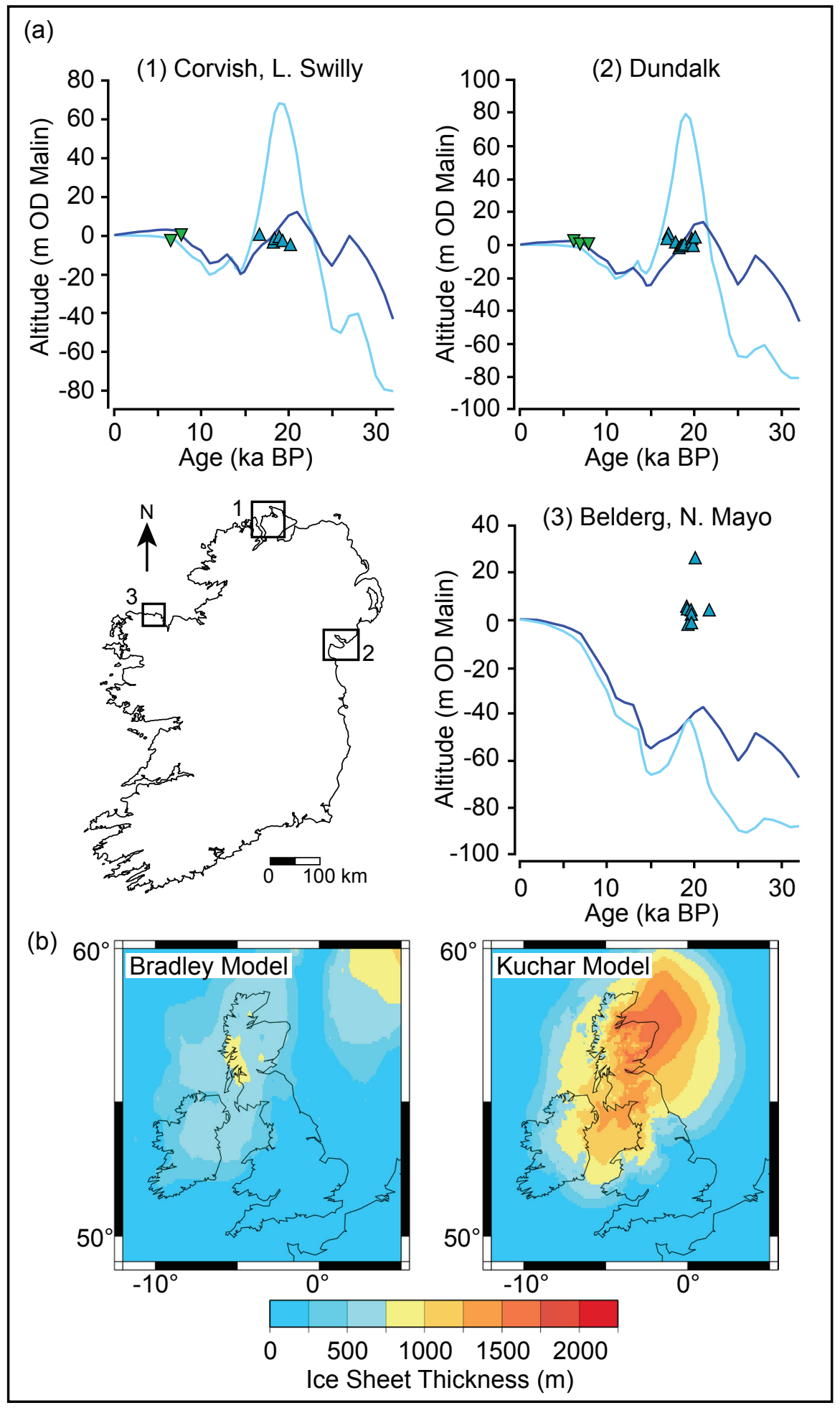




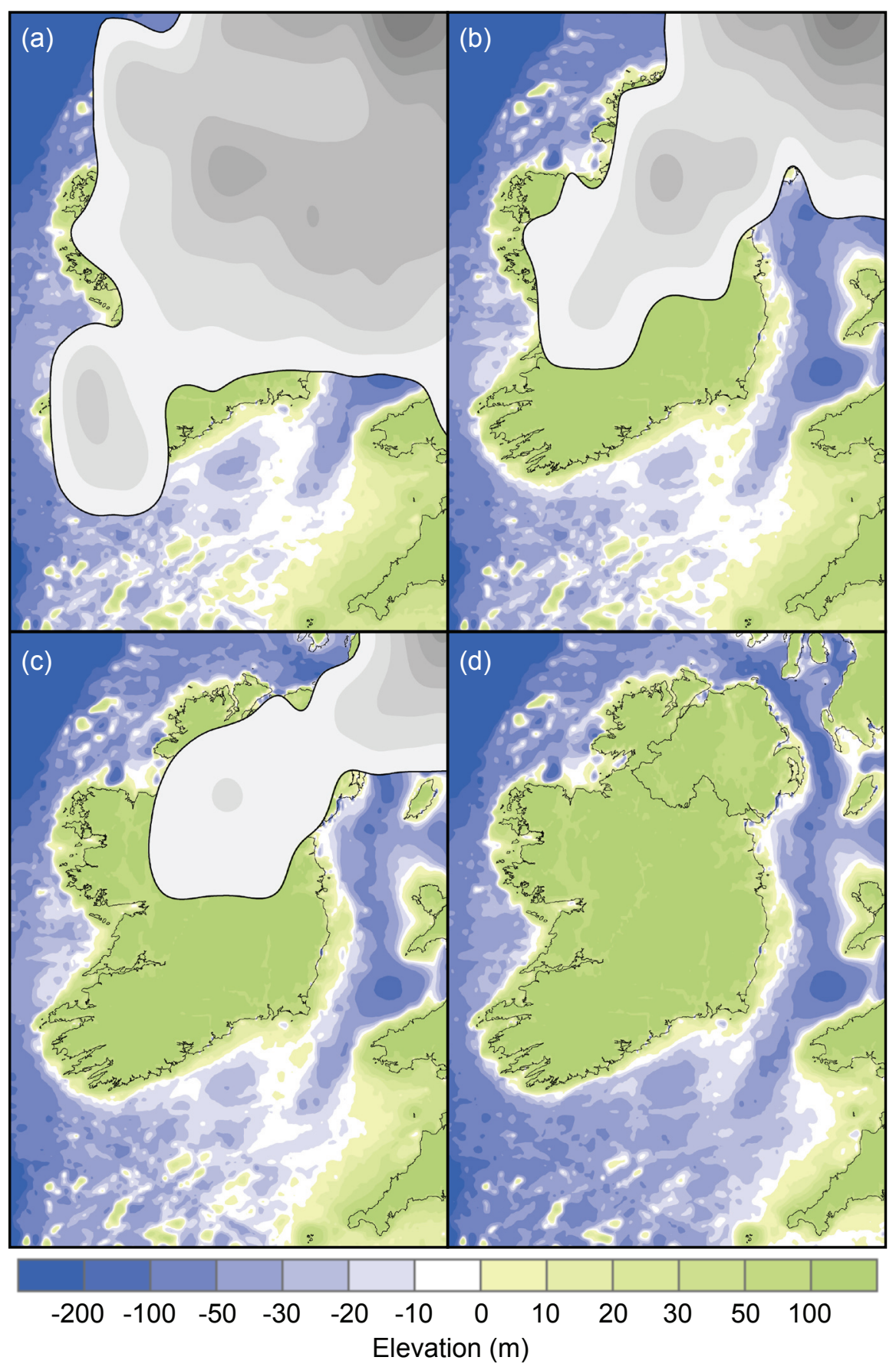

